\title{
Structure Assignment of Seized Products Containing Cathinone Derivatives Using High Resolution Analytical Techniques
}

\author{
João L. Gonçalves ${ }^{1, *(\mathbb{D})}$, Vera L. Alves ${ }^{1}{ }^{\mathbb{D}}$, Joselin Aguiar ${ }^{1}$, Maria J. Caldeira ${ }^{2}$, Helena M. Teixeira ${ }^{3,4}$ and \\ José S. Câmara $1,5, * \mathbb{D}$ \\ 1 CQM-Centro de Química da Madeira, Campus Universitário da Penteada, Universidade da Madeira, \\ 9020-105 Funchal, Portugal; vera.alves@staff.uma.pt (V.L.A.); joselin.aguiar@staff.uma.pt (J.A.) \\ 2 Laboratório de Polícia Científica da Polícia Judiciária, Novo edifício-sede da Polícia Judiciária, Rua Gomes \\ Freire, 1169-007 Lisboa, Portugal; joao.caldeira@pj.pt \\ 3 Instituto Nacional de Medicina Legal e Ciências Forenses, I.P., Polo das Ciências de Saúde (Polo III), Azinhaga \\ de Santa Comba, 3000-548 Coimbra, Portugal; helena.m.teixeira@inmlcf.mj.pt \\ 4 Faculdade de Medicina da Universidade de Coimbra, Azinhaga de Santa Comba, Celas, \\ 3000-548 Coimbra, Portugal \\ 5 Faculdade de Ciências Exatas e da Engenharia, Campus da Penteada, Universidade da Madeira, \\ 9020-105 Funchal, Portugal \\ * Correspondence: jluis@staff.uma.pt (J.L.G.); jsc@staff.uma.pt (J.S.C.)
}

check for updates

Citation: Gonçalves, J.L.; Alves, V.L.; Aguiar, J.; Caldeira, M.J.; Teixeira, H.M.; Câmara, J.S. Structure Assignment of Seized Products Containing Cathinone Derivatives Using High Resolution Analytical Techniques. Metabolites 2021, 11, 144. https://doi.org/10.3390/ metabo11030144

Academic Editor: Cornelius Hess

Received: 1 February 2021

Accepted: 24 February 2021

Published: 27 February 2021

Publisher's Note: MDPI stays neutral with regard to jurisdictional claims in published maps and institutional affiliations.

Copyright: (c) 2021 by the authors. Licensee MDPI, Basel, Switzerland. This article is an open access article distributed under the terms and conditions of the Creative Commons Attribution (CC BY) license (https:// creativecommons.org/licenses/by/ $4.0 /)$

\begin{abstract}
The innovation of the new psychoactive substances (NPS) market requires the rapid identification of new substances that can be a risk to public health, in order to reduce the damage from their use. Twelve seized products suspected to contain illicit substances were analyzed by attenuated total reflectance Fourier transform infrared spectroscopy (ATR-FTIR), gas chromatography coupled to mass spectrometry (GC-MS), and nuclear magnetic resonance spectroscopy (NMR). Synthetic cathinones (SCat) were found in all products, either as a single component or in mixtures. Infrared spectra of all products were consistent with the molecular structure of SCat, showing an intense absorption band at $1700-1674 \mathrm{~cm}^{-1}$, corresponding to the carbonyl stretching, a medium/strong peak at $1605-1580 \mathrm{~cm}^{-1}$, indicating stretching vibrations in the aromatic ring $(C=C)$ and bands with relative low intensity at frequencies near $2700-2400 \mathrm{~cm}^{-1}$, corresponding to an amine salt. It was possible to identify a total of eight cathinone derivatives by GC-MS and NMR analysis: $4^{\prime}$-methyl- $\alpha$ pyrrolidinohexanophenone (MPHP), $\alpha$-pyrrolidinohexanophenone ( $\alpha$-PHP), 3-fluoromethcathinone (3-FMC), methedrone, methylone, buphedrone, $N$-ethylcathinone, and pentedrone. Among the adulterants found in these samples, caffeine was the most frequently detected substance, followed by ethylphenidate. These results highlight the prevalence of SCat in seized materials of the Portuguese market. Reference standards are usually required for confirmation, but when reference materials are not available, the combination of complementary techniques is fundamental for a rapid and an unequivocal identification of such substances.
\end{abstract}

Keywords: chemical characterization; new psychoactive substances; synthetic cathinones; FTIR GC-MS; NMR

\section{Introduction}

In the last two decades, a tremendous change in the illicit drug market has become evident, with the emergence of a "new generation" of psychoactive substances [1]. Mimicking the effects of illicit drugs, and sometimes being traded alongside them, these NPS have introduced many challenges to legal systems, as well as emergency and drug treatment services [2]. Among these substances, SCat rapidly gained popularity, especially among young people, and currently constitute the second largest group of NPS monitored in Europe, with almost 140 identified substances so far $[3,4]$.

Natural cathinone, which is the major active component of the Khat plant (Catha edulis Forsk), has been used as a prototype for the development of numerous synthetic 
derivatives $[5,6]$. In general, functional group substitutions in the cathinone occur in three distinct regions of the molecule, namely the amino group, the alkyl side chain, and the aromatic ring (Figure 1), which has led to a multitude of derivatives to the street and cyber drug markets $[7,8]$.

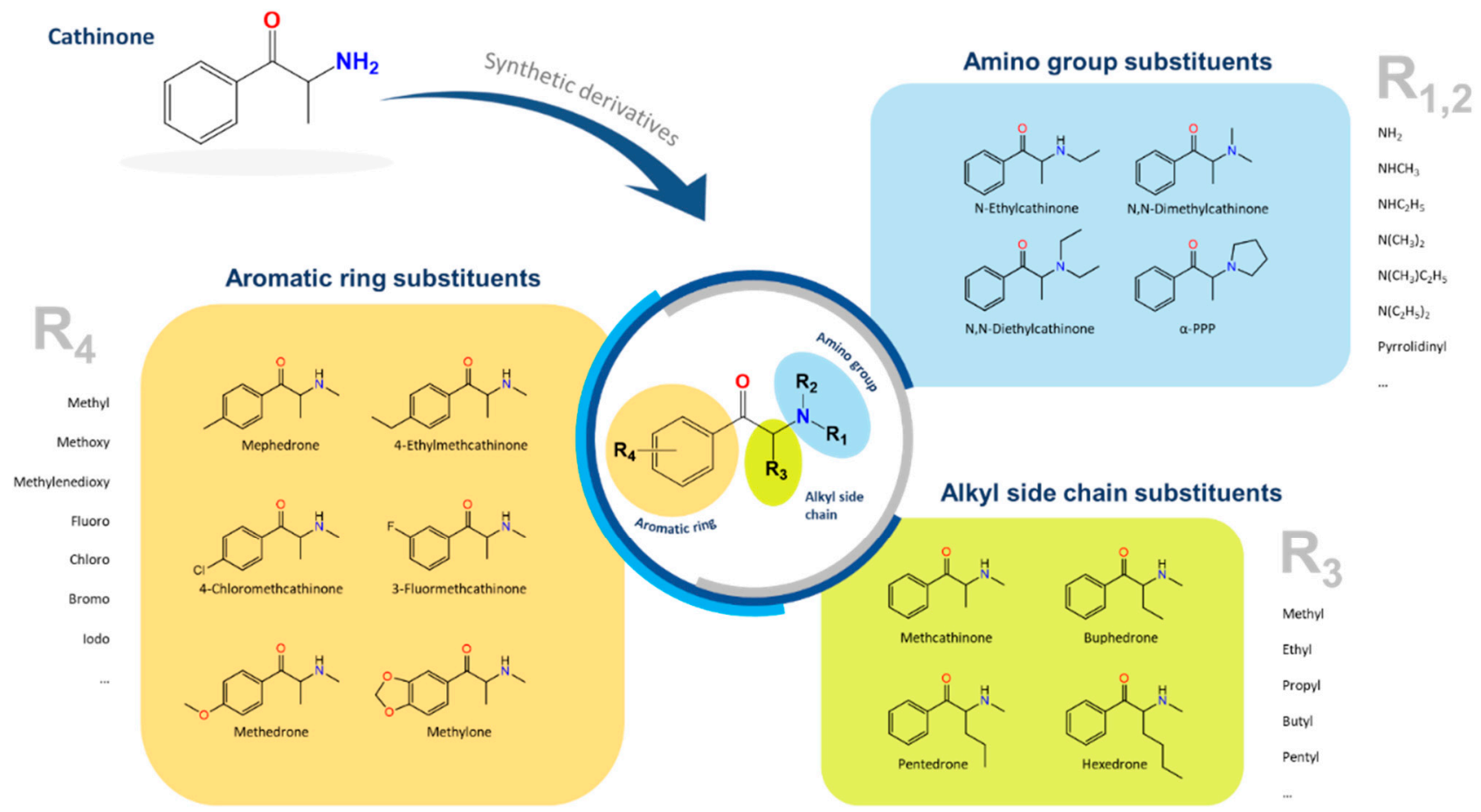

Figure 1. General chemical structure of SCat and some representative examples of functional group substituents on the aromatic ring, the alkyl side chain and the amino group.

SCat can be found on the market in products sold as "bath salts" or "plant feeders", in different forms, including tablets, capsules, crystals or powders [1,9]. These substances are usually taken orally, either by swallowing capsules or 'bombing', where the powder is wrapped in a cigarette paper and subsequently swallowed [10,11]. Inhalation is another common mode of administration of these substances, whereas gingival delivery, intravenous or intramuscular injection and rectal administration are less common routes [11,12].

Similarly to other stimulant drugs like cocaine or 3,4-methylenedioxymethamphetamine (MDMA), SCat interact with monoamine membrane transporters, leading to an increase in serotonin concentrations (5-HT), dopamine (DA) and noradrenaline (NA) $[8,10,13]$. In general, these substances create a feeling of euphoria, alertness, empathy, and increased libido, being highly sought after as an alternative to traditional drugs of abuse [14,15]. However, the consumption of SCat can lead to a varied and unpredictable number of side effects, and in many cases, are linked to aggression and violent behavior [16,17]. Despite their relatively short time on the clandestine market, SCat have been responsible for several cases of acute poisonings and fatal overdoses [18-21]. Acute intoxication with SCat can produce a wide range of symptoms, including psychiatric disturbances (panic attacks, hallucinations, paranoid psychosis, and suicidal ideations), sympathomimetic toxidrome (agitation, increased aggression, hypertension, tachycardia, chest pain, cardiac arrest), seizures, acid-base imbalance and multi-organ failure [1,4,22,23]. In general, the most frequent cause of intoxication and fatalities is related to the unknowledge about the product content and its purity, or even with the concentration of the psychoactive substance(s) in the administered dose [24].

Up to now, many efforts and some progress has been made to control the sale and distribution of these substances. From temporary banning orders to consumer legislation, 
governments are using a host of tools in an attempt to curtail the free sale and distribution of these products [2]. In Portugal, the commercialization of SCat has been outlawed since 2013, after the introduction of the Decree-Law no. 54/2013, of 17 April, which defines the legal framework for the prevention and protection against the advertising and commerce of the NPS and forbids the production, importation, exportation, publicity, distribution, possession and selling of 159 NPS, including 34 SCat [25]. Despite measures that have helped to reduce the supply of NPS, by closing down the so-called "smartshops" (retail establishments specialized in selling psychoactive substances and related paraphernalia), SCat continue to appear in the drug market and its abuse still represents a public health issue.

The ever-evolving nature of these substances has created many analytical challenges for forensic and chemistry laboratories, due to the large number of potential compounds to be investigated, and for which there are no available reference standards [26,27].

Although it is possible to routinely analyze the already identified substances, using appropriate instrumentation, such as liquid or gas chromatography coupled to mass spectrometry (LC-MS and GC-MS), the identification of unknown substances generally requires a structural elucidation before being included in routine methods [28]. Typically, this process requires the use of NMR spectroscopy to identify the chemical structure of the compound. However, the structural similarities of some substances, such as the SCat, may offer analytical challenges, which make the analysis particularly difficult. In such situations, the selection of analytical techniques can be challenging, since each technique has its own advantages that may be more or less suitable, depending on the situations. This highlights the importance of using complementary analytical techniques to confirm the identity of a substance [28].

In this context, the present study describes and discusses the analytical assays performed to identify the components of 12 products seized in Portugal, suspected to contain SCat. Structure elucidation of compounds was carried out by ATR-FTIR, GC-MS and NMR spectroscopy.

\section{Results and Discussion}

The identification of products containing NPS is a challenging task, as the present substances do not generally correspond to the label, and can contain a wide range of impurities and/or adulterants [23]. The products were presented in brightly colored packaging or, occasionally, in transparent plastic bags with the trade name, the supposed composition, the product quantity along with the warning "not for human consumption". Most products (83\%) were in powder form, and only two products were presented in the crystal (product 2) and tablets (product 10) forms (Table 1). The predominant color of the powders and tablets were white, whereas the crystal had a brownish color. In relation to the composition indicated on the packaging, all had "ketones" in the list of ingredients, presumably indicative of the presence of Scat, except products 1 and 2 . In addition, most powder products also referred the presence of caffeine and glucose. The composition indicated on the packaging of the tablets was more elaborated, with the information of the active principle and of other excipients related to the production of the tablets.

Table 1. List of provided samples with the information about their chemical composition indicated on the product label.

\begin{tabular}{|c|c|c|c|c|c|}
\hline $\begin{array}{l}\text { Sample } \\
\text { Number }\end{array}$ & $\begin{array}{l}\text { Product } \\
\text { Name }\end{array}$ & Description & Appearance & Quantity (g) & Composition Indicated on the Label \\
\hline 1 & Unknown & n.a. ${ }^{1}$ & White powder & 1 & n.a. ${ }^{1}$ \\
\hline 2 & Flakka & n.a. ${ }^{1}$ & Brownish crystal & 5 & n.a. ${ }^{1}$ \\
\hline 3 & Bloom & Plant feeder & White powder & 1 & $94 \%$ Ketones, $5 \%$ caffeine, $1 \%$ glucose \\
\hline 4 & Bloom & Plant feeder & White powder & 1 & $94 \%$ Ketones, $5 \%$ caffeine, $1 \%$ glucose \\
\hline 5 & Bloom & Plant feeder & White powder & 1 & $94 \%$ Ketones, $5 \%$ caffeine, $1 \%$ glucose \\
\hline 6 & Bloom & Plant feeder & White powder & 1 & $94 \%$ Ketones, $5 \%$ caffeine, $1 \%$ glucose \\
\hline 7 & Bloom & Plant feeder & White powder & 1 & $94 \%$ Ketones, $5 \%$ caffeine, $1 \%$ glucose \\
\hline 8 & Charlie & Plant feeder & Light yellow powder & 1 & $100 \%$ Ketones \\
\hline 9 & Bliss & Plant feeder & White powder & 1 & $94 \%$ Ketones, $5 \%$ caffeine, $1 \%$ glucose \\
\hline
\end{tabular}


Table 1. Cont.

\begin{tabular}{|c|c|c|c|c|c|}
\hline $\begin{array}{l}\text { Sample } \\
\text { Number }\end{array}$ & $\begin{array}{l}\text { Product } \\
\text { Name }\end{array}$ & Description & Appearance & Quantity (g) & Composition Indicated on the Label \\
\hline 10 & Bliss & Plant feeder & White tablets & 5 tablets & $\begin{array}{l}\text { Per Pill: } 120 \mathrm{mg} \text { lactose, } 20 \mathrm{mg} \text { magnesium } \\
\text { stearate, } 100 \mathrm{mg} \text { corn starch, } 160 \mathrm{mg} \text { ketones, } \\
50 \mathrm{mg} \text { calcium stearate, } 4 \mathrm{mg} \text { E142, } 6 \mathrm{mg} \\
\text { E132, } 20 \mathrm{mg} \text { E124 }\end{array}$ \\
\hline 11 & Blast & Plant feeder & White powder & 1 & $89 \%$ Ketones, $10 \%$ caffeine, $1 \%$ glucose \\
\hline 12 & Kick & Plant feeder & White powder & 1 & $94 \%$ Ketones, $5 \%$ caffeine, $1 \%$ glucose \\
\hline
\end{tabular}

\subsection{ATR-FTIR Analysis}

The infrared spectra of all seized materials were consistent with the molecular structure of SCat (Figure S1 Supplementary Material). All spectra showed a prominent absorption band around $1700-1674 \mathrm{~cm}^{-1}$ that corresponds to the carbonyl group stretching $(\mathrm{C}=\mathrm{O})$.

The intensity of this band exhibited variation among the samples, but was the major peak in many cases. Bands observed at $3063-3024 \mathrm{~cm}^{-1}$ and $2952-2711 \mathrm{~cm}^{-1}$ can be assigned to aryl $\mathrm{C}-\mathrm{H}$ and alkyl $\mathrm{C}-\mathrm{H}$ stretch vibration, respectively. On the other hand, the medium/strong band observed at $1605-1580 \mathrm{~cm}^{-1}$ can indicate stretch aromatic ring vibrations $(C=C)$, while a set of bands in the range of $2700-2400 \mathrm{~cm}^{-1}$ can be assigned to the amine salt $[28,29]$. Figure 2 describes an example of the infrared bands identified in one seized product (product 8).

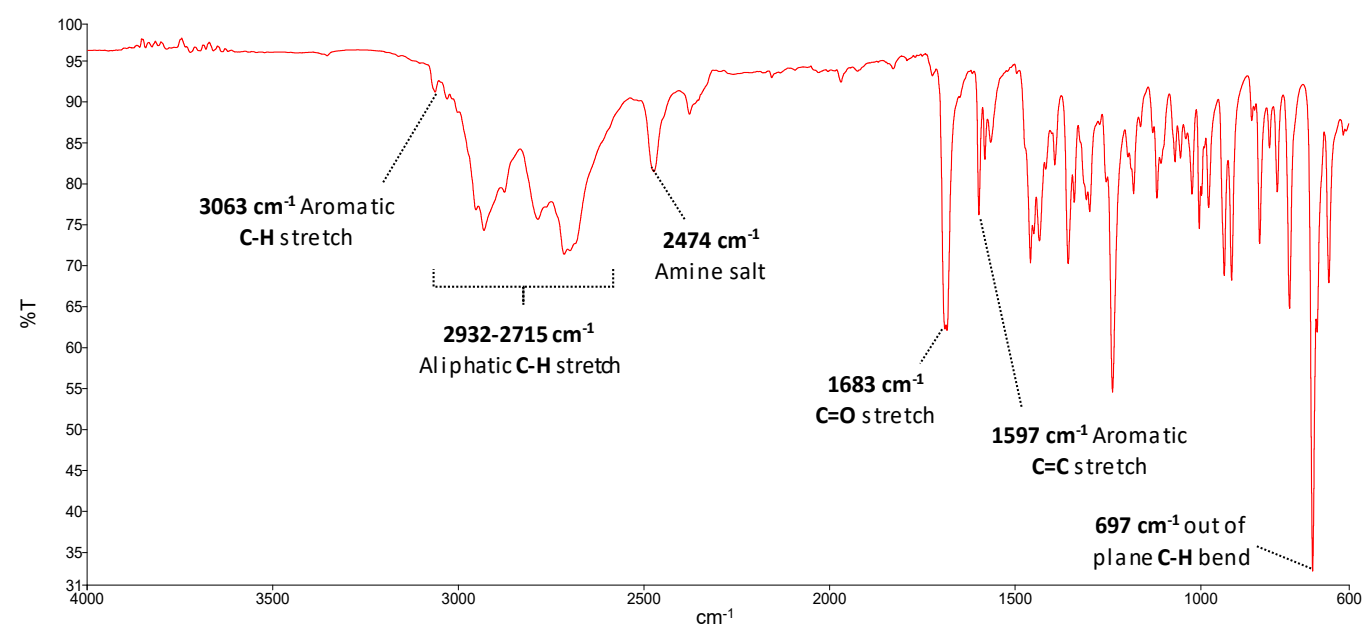

Figure 2. FTIR spectrum of product 8 ("Charlie").

For absorptions below $1500 \mathrm{~cm}^{-1}$, the differences between samples were more significant. A strong band observed in products 9 and 10 at $1259 \mathrm{~cm}^{-1}$ dominates the IR spectrum and could indicate a $\mathrm{C}-\mathrm{O}-\mathrm{C}$ stretching $[30,31]$. In general, the out-of-plane $\mathrm{C}-\mathrm{H}$ bending bands in the region of $675-900 \mathrm{~cm}^{-1}$ are used to differentiate between substituted aromatic compounds [32,33]. For monosubstituted benzene rings, out-of-plane $\mathrm{C}-\mathrm{H}$ bending bands fall between $770-730 \mathrm{~cm}^{-1}$ and $710-690 \mathrm{~cm}^{-1}$ and are often the most intense bands in the spectra [32,34]. In this sense, products $2-8$ and 12 showed a pattern consistent with these characteristics, indicating that we may be facing compounds with monosubstituted aromatic rings. It is important to note that "Bloom" products (products 3-7) had identical IR spectra, which may indicate that they have the same chemical composition.

\subsection{GC-MS Analysis}

Methanolic solutions of the seized materials were directly analyzed by GC-MS, resulting in different chromatographic profiles (Figure S2, Supplementary Information). The EI mass spectra for most compounds were consistent with the fragmentation pattern of 
SCat, showing the presence of iminium cations as the base peak and small or absent intensities of the molecular ions (Figure 3). Table 2 shows the identified compounds, their molecular formulas, retention time, the base peak and other characteristic ions for the identified compounds.
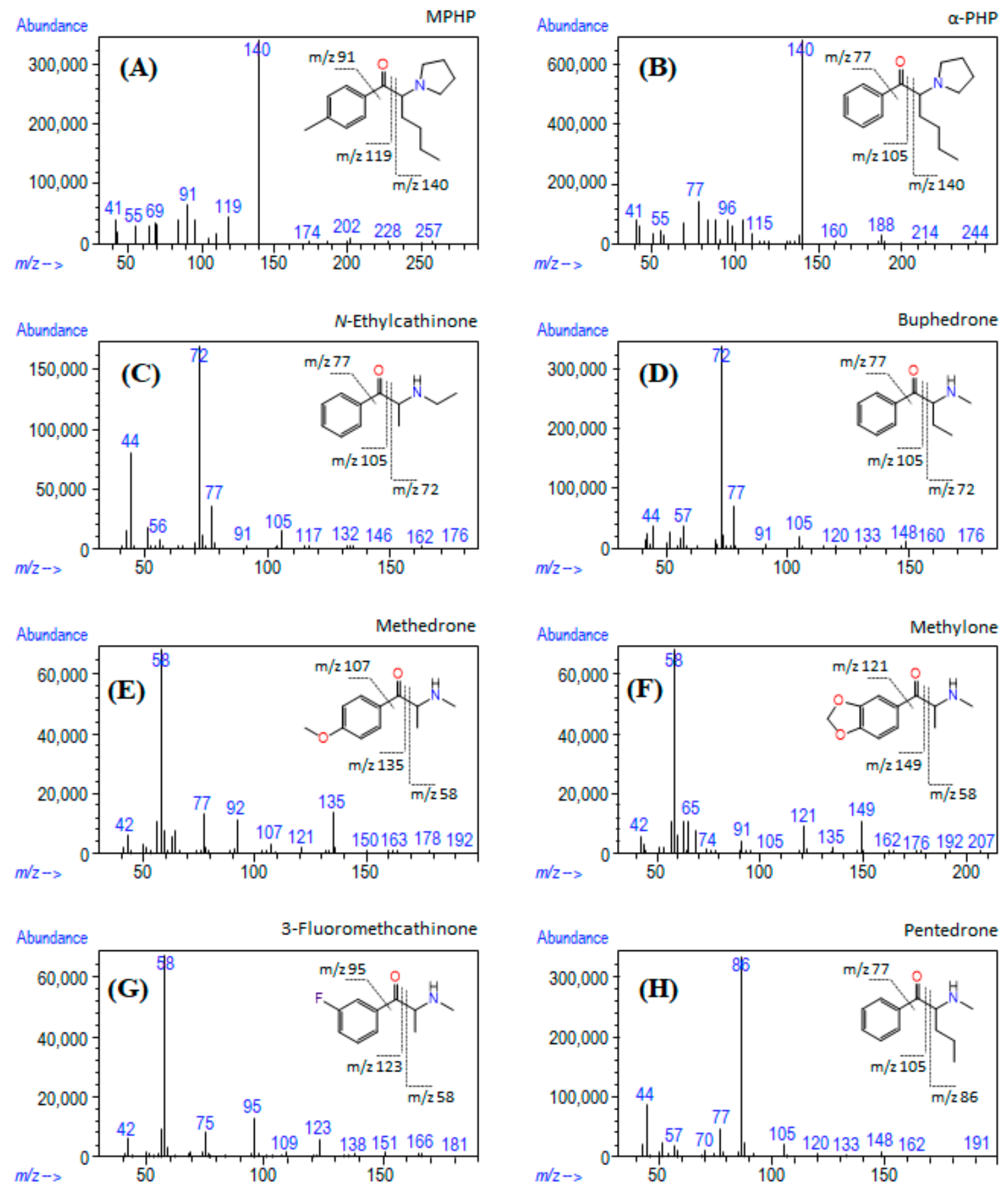

Figure 3. EI mass spectra of (A) MPHP, (B) $\alpha$-PHP, (C) N-ethylcathinone, (D) buphedrone, (E) methedrone, (F) methylone, (G) 3-FMC and (H) pentedrone found in seized products. 
Table 2. Active substances detected by GC-MS, with the respective retention times (RT), molecular formula (MF), molecular weight (MW), base peak and other characteristic ions.

\begin{tabular}{|c|c|c|c|c|c|c|c|c|c|}
\hline \multirow[b]{2}{*}{ Peak No. } & \multirow[b]{2}{*}{ Compound Name } & \multicolumn{4}{|c|}{ Direct Analysis } & \multicolumn{4}{|c|}{ Derivatization with TFAA } \\
\hline & & RT (min) & MF & MW & Ions $(m / z)$ & $\begin{array}{c}\mathrm{RT} \\
(\mathrm{min})\end{array}$ & MF & MW & Ions $(m / z)$ \\
\hline 1 & MPHP 1 & 18.654 & $\mathrm{C}_{17} \mathrm{H}_{25} \mathrm{NO}$ & 259 & $140,91,119,41$ & - & - & - & - \\
\hline 2 & $\alpha-\mathrm{PHP}^{1}$ & 17.950 & $\mathrm{C}_{17} \mathrm{H}_{25} \mathrm{NO}$ & 245 & $140,77,96,105$ & - & - & - & - \\
\hline 3 & $N$-Ethylcathinone & 10.658 & $\mathrm{C}_{11} \mathrm{H}_{15} \mathrm{NO}$ & 177 & $72,44,77,105$ & 12.173 & $\mathrm{C}_{13} \mathrm{H}_{14} \mathrm{~F}_{3} \mathrm{NO}_{2}$ & 273 & $\mathbf{1 6 8}, 105,140,77$ \\
\hline 4 & Buphedrone & 10.785 & $\mathrm{C}_{11} \mathrm{H}_{15} \mathrm{NO}$ & 177 & $72,77,44,105$ & 11.813 & $\mathrm{C}_{13} \mathrm{H}_{14} \mathrm{~F}_{3} \mathrm{NO}_{2}$ & 273 & $\mathbf{1 6 8}, 105,77,110$ \\
\hline 5 & Methedrone & 14.820 & $\mathrm{C}_{11} \mathrm{H}_{15} \mathrm{NO}_{2}$ & 193 & $58,135,77,92$ & 16.096 & $\mathrm{C}_{13} \mathrm{H}_{14} \mathrm{~F}_{3} \mathrm{NO}_{3}$ & 289 & $135,77,154,92$ \\
\hline 6 & Ethylphenidate & 17.357 & $\mathrm{C}_{14} \mathrm{H}_{19} \mathrm{NO}_{2}$ & 233 & $84,91,56,164$ & 18.538 & $\mathrm{C}_{17} \mathrm{H}_{20} \mathrm{~F}_{3} \mathrm{NO}_{3}$ & 343 & $180,164,67,55$ \\
\hline 7 & Caffeine ${ }^{1}$ & 17.775 & $\mathrm{C}_{8} \mathrm{H}_{10} \mathrm{~N}_{4} \mathrm{O}_{2}$ & 194 & $194,109,67,55$ & - & - & - & - \\
\hline 8 & Methylone & 16.314 & $\mathrm{C}_{11} \mathrm{H}_{13} \mathrm{NO}_{3}$ & 207 & $58,149,65,121$ & 17.239 & $\mathrm{C}_{13} \mathrm{H}_{12} \mathrm{~F}_{3} \mathrm{NO}_{4}$ & 303 & $149,154,121,110$ \\
\hline 9 & 3-FMC & 10.007 & $\mathrm{C}_{10} \mathrm{H}_{12} \mathrm{FNO}$ & 181 & $58,95,75,123$ & 10.837 & $\mathrm{C}_{12} \mathrm{H}_{11} \mathrm{~F}_{4} \mathrm{NO}_{2}$ & 277 & $\mathbf{1 5 4}, 110,123,95$ \\
\hline 10 & Isopentedrone & 11.516 & $\mathrm{C}_{12} \mathrm{H}_{17} \mathrm{NO}$ & 191 & $120,42,118,91$ & 13.239 & $\mathrm{C}_{14} \mathrm{H}_{16} \mathrm{~F}_{3} \mathrm{NO}_{2}$ & 287 & $110,216,182,140$ \\
\hline 11 & Pentedrone & 12.083 & $\mathrm{C}_{12} \mathrm{H}_{17} \mathrm{NO}$ & 191 & $86,44,77,105$ & 13.098 & $\mathrm{C}_{14} \mathrm{H}_{16} \mathrm{~F}_{3} \mathrm{NO}_{2}$ & 287 & $\mathbf{1 8 2}, 140,105,77$ \\
\hline
\end{tabular}

${ }^{1}$ Derivatization did not occur; Bold numbers: base peak ion.

As reported by Zuba [35], the $\alpha$-cleavage process is a key feature of the mass spectral fragmentation of SCat. This process results in the formation of the iminium ion by fragmentation of the $\mathrm{C}-\mathrm{C}$ bond between the $\alpha$ and $\beta$ carbon atoms under EI conditions (Figure 4). In the case of cathinones with a straight-chained aliphatic side ring, the structural formula of the base iminium ion is represented by $\mathrm{C}_{n} \mathrm{H}_{2 n+2} \mathrm{~N}^{+}(n=1,2, \ldots)$, resulting in a base peak of mass-to-charge ratio $(\mathrm{m} / \mathrm{z}) 44,58,72,86,100$ and so on, depending on the number of carbon atoms contained in the iminium ion $[35,36]$. N-Ethylcathinone, buphedrone, pentedrone, methedrone, methylone and 3-FMC are SCat that produce typical $\mathrm{C}_{n} \mathrm{H}_{2 \mathrm{n}+2} \mathrm{~N}^{+}$ iminium ions. For cathinones with a pyrrolidine ring in the side chain, such as MPHP and $\alpha$-PHP, fragmentation leads to the formation of characteristic ions represented by the structural formula $\mathrm{C}_{\mathrm{n}} \mathrm{H}_{2 \mathrm{n}} \mathrm{N}^{+}(n=5,6, \ldots)$, which corresponds to $\mathrm{R}_{3} \mathrm{CH}=\mathrm{N}^{+}\left(\mathrm{C}_{4} \mathrm{H}_{8}\right)$ species [35]. The consequent fragmentation of the pyrrolidine ring leads to the formation of characteristic ions $m / z 70,55,42$ and 41 [35,37].

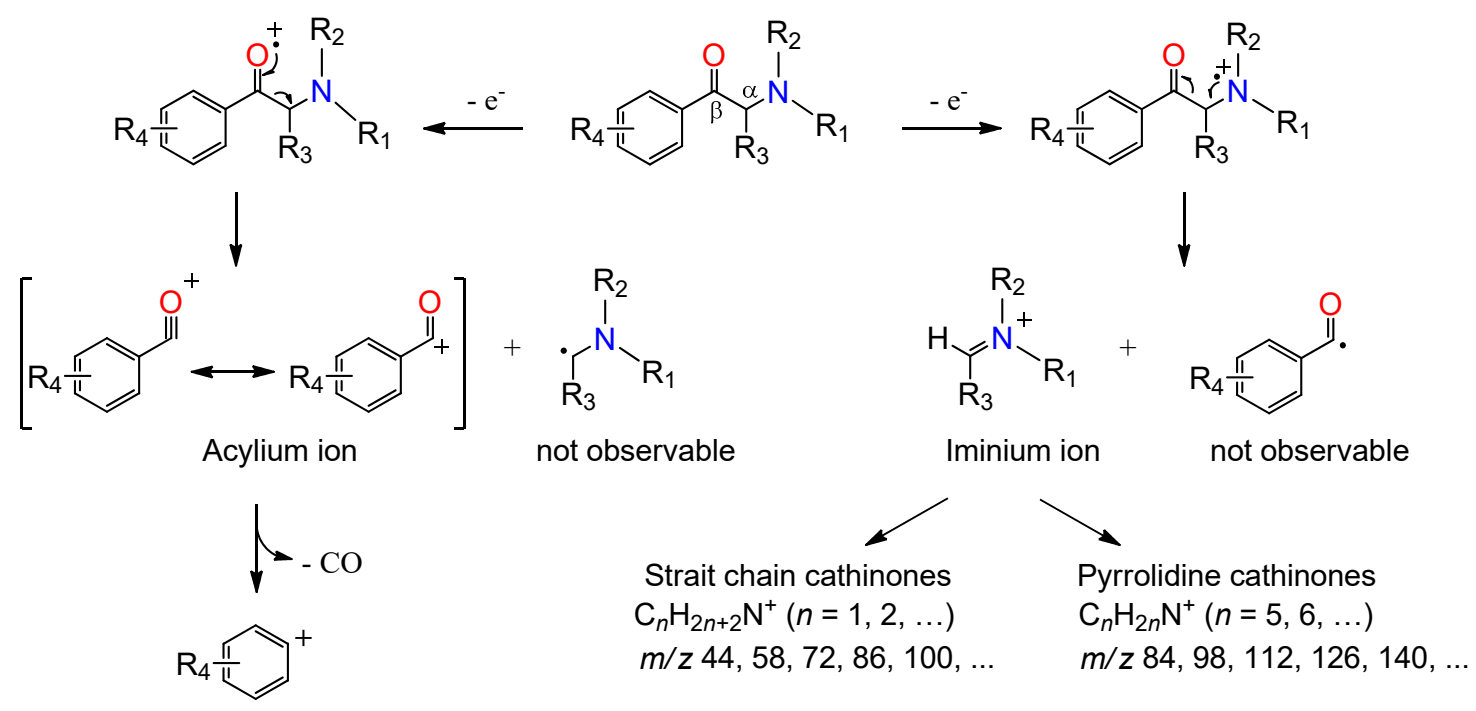

Figure 4. General mass spectra fragmentation pattern of SCat under EI conditions (adapted from Zuba [35]).

Another common reaction observed in SCat under EI condition is the formation of the acylium ion. In general, this process takes place at the same location as for the formation of the iminium ion and involves the dissociation of the $C_{\alpha}-C_{\beta}$ bond, leaving behind an acylium ion [36]. The consequent loss of carbon monoxide (CO) from the acylium ion results in the formation of the phenyl cation, as indicated in Figure 4. The phenyl $(\mathrm{m} / \mathrm{z}$ 77), methylphenyl ( $m / z$ 91), and fluorophenyl $(\mathrm{m} / z$ 95) cations are some representative examples of ions produced by the loss of carbon monoxide from the corresponding acylium ions at $m / z 105$ (benzoyl ion), 119 (methylbenzoyl ion) and 123 (fluorobenzoyl ion). Al- 
though these fragmentation patterns in the mass spectra provide structural information about the elemental composition, they do not differentiate structural isomers with different substitution patterns on the aromatic ring.

Unfortunately, the EI method is often limited to differentiate structurally similar cathinones. The similar fragmentation patterns in some of these compounds, associated with the absence of molecular ion peak, may produce ambiguous mass spectra [38]. However, the differentiation of these compounds can be achieved using an alternative approach, such as chemical derivatization, which can represent a straightforward and cost-effective way to improve the capability of compound identification $[39,40]$.

TFAA is one of the most widely used derivatizing agents, known to react with the primary and secondary amine groups of the amphetamine-type stimulants [41,42]. Derivatives are formed via acylation, where the amine hydrogen is removed and replaced with a trifluoroacyl group [43]. Not all substituted cathinones can be directly derivatized using TFAA, which requires, at least, one hydrogen atom in the amino group or an active hydrogen atom from other functional groups (e.g., $-\mathrm{OH},-\mathrm{COOH})$.

After derivatization and knowing the molecular weight and ions resulting from fragmentation, it was possible to identify the chemical structures of the formed compounds. Figure S3 (Supplementary Information) shows the typical GC-MS chromatograms of the seized products after derivatization with TFAA, and Figure 5 describes the respective mass spectra of SCat after derivatization. Table 2 shows the identified TFAA derivative compounds, their molecular formulas, retention time, the base peak and other characteristic ions for the identified compounds.
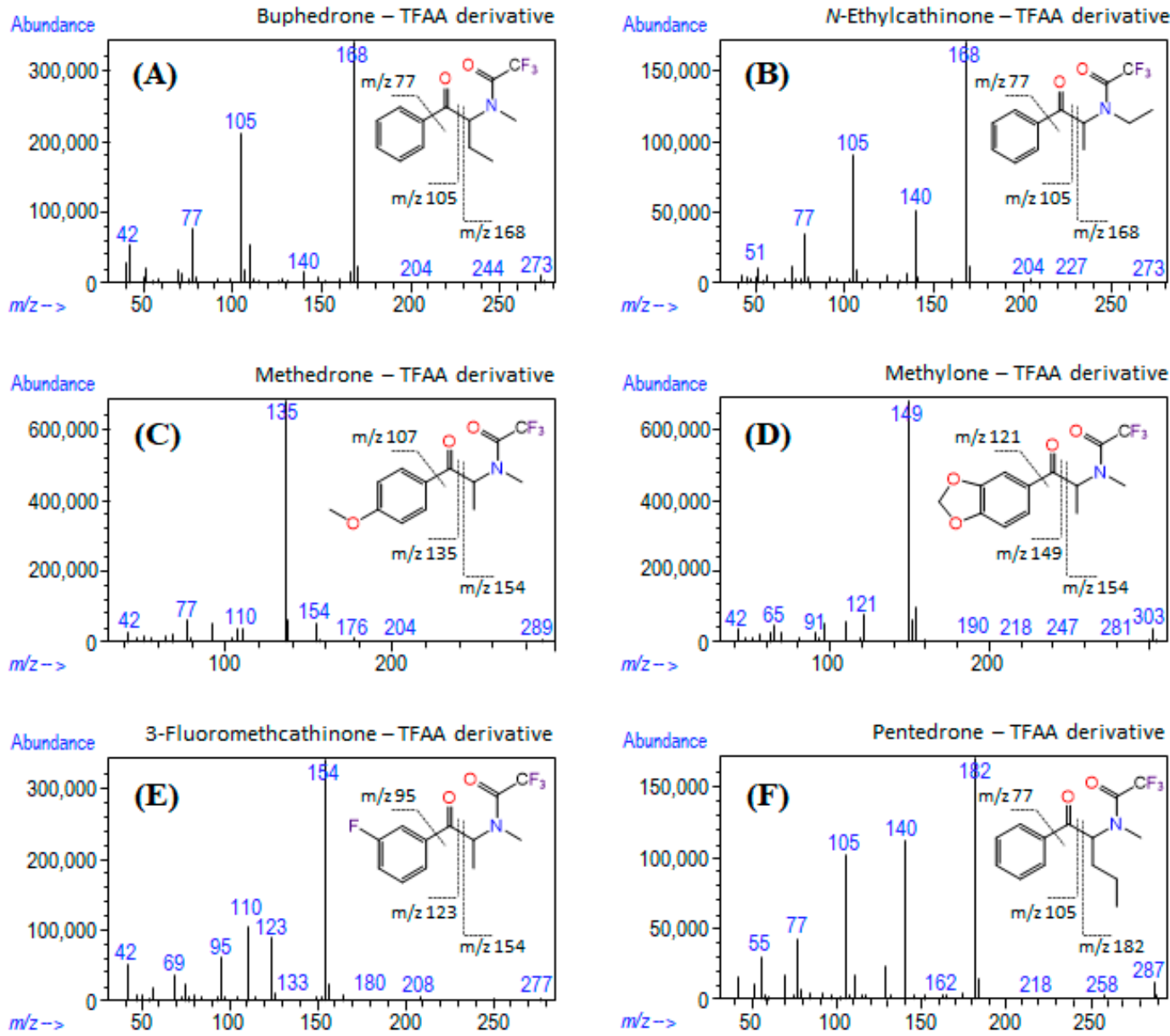

Figure 5. EI mass spectra of (A) buphedrone (B) N-ethylcathinone (C) methedrone (D) methylone (E) 3-FMC and (F) pentedrone after derivatization with TFAA. 
Derivatization of SCat with TFAA produced a better chromatographic resolution and increased mass spectral abundances for molecular and fragment ions. Before derivatization, products containing $\mathrm{N}$-ethylcathinone and buphedrone (products 3-8) had a poor resolution, and the fragmentation patterns observed on the mass spectra of both compounds were very similar. After derivatization, these SCat showed better chromatographic separation, with larger, narrower, and more symmetric chromatographic peaks, and the mass fragmentation pattern of both compounds were readily distinguished by the different relative abundance of two common fragment ions $(\mathrm{m} / z 140$ and 110$)$. In general, SCat with a methyl substituent on the nitrogen atom, such as buphedrone, have a characteristic ion at $m / z 110$ $\left(\left[\mathrm{CH}_{3}-\mathrm{N} \equiv \mathrm{C}-\mathrm{CF}_{3}\right]^{+}\right)$. This cation may be formed from the decomposition reaction of the TFAA imine specie at $m / z 168$ (Figure 6A). $N$-Ethylcathinone with an ethyl substituent in the amino group produced analogous cation at $m / z 124$ corresponding to $\left[\mathrm{C}_{2} \mathrm{H}_{5}-\mathrm{N} \equiv \mathrm{C}-\mathrm{CF}_{3}\right]^{+}$ (Figure 6B), with low relative abundance ( $2 \%)$. In addition, both compounds showed a characteristic ion at $m / z 140$. This cation is more abundant in $N$-ethylcathinone (29\%) than in buphedrone (4\%) and is probably originated from a rearrangement of the ethyl group of the $m / z 168$ cation to lose ethylene.

A

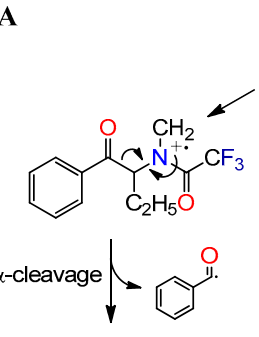

$\mathrm{CH}_{3}$

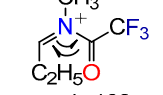

(

$\mathrm{CH}_{3}-\mathrm{N} \equiv \mathrm{C}-\mathrm{CF}_{3}$

$\mathrm{m} / \mathrm{z} 110$

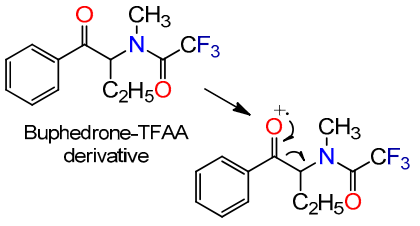

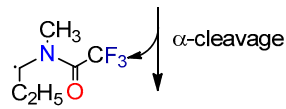

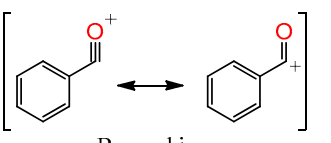

Benzoyl ion

$m / z 105$
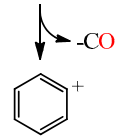

Phenyl ion
$\mathrm{m} / \mathrm{z} 77$

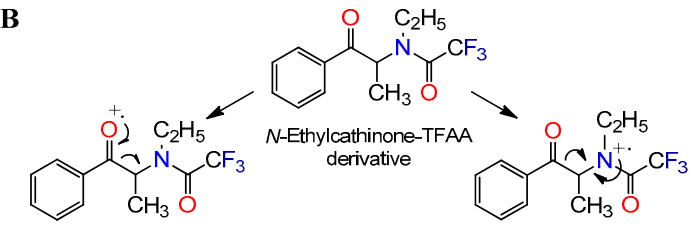

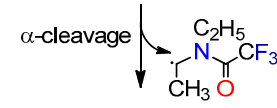

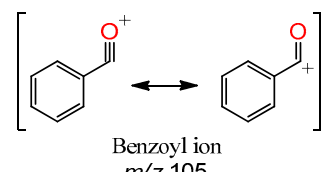

$m / z 105$

$\gamma-\mathrm{CO}$

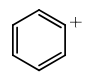

Phenyl ion

$m / z 77$

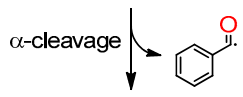

$\mathrm{C}_{2} \mathrm{H}_{5}$

$\stackrel{\mathrm{CH}}{\mathrm{C}}_{\mathrm{C}_{3}^{+}}^{\dot{\mathrm{N}}_{\mathrm{O}}^{+}} \mathrm{CF}_{3}$

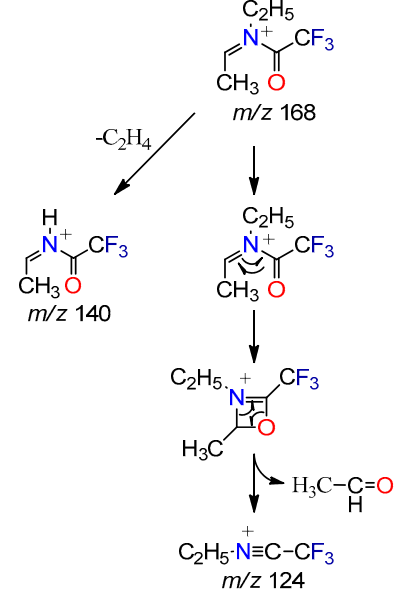

Figure 6. Probable fragmentation pathways of TFAA derivatives of, (A) buphedrone, and (B) N-ethylcathinone.

We can conclude, based on these results and considering the number of potential compounds to be investigated, associated to the lack of reference standards and the existence of a wide diversity of isomers with identical fragmentation patterns under EI conditions, that the derivatization with TFAA showed to be an effective strategy to confirm the identity of these substances, allowing us to obtain more specific structural information of these compounds. Thus, through the GC-MS analysis, it was possible to identify a total of 11 different substances, belonging, the most of them, to the class of SCat. MPHP was identified as the main compound in product 1, while $\alpha$-PHP was the main component in product 2. Both substances showed characteristic mass spectral fragmentation pattern with SCat containing a pyrrolidine ring in the side chain. Methylone was identified as the main component in product 10, and together with caffeine in product 9. "Bloom" products (products 3-7) had a similar chromatographic profile and identical chemical composition, which means that they probably belong to the same batch. $N$-Ethylcathinone, buphedrone, 
methedrone, caffeine and ethylphenidate were the identified substances in these samples. It was also confirmed by GC-MS that products 8,11 and 12 contained $N$-ethylcathinone, making this SCat the most frequently detected psychoactive substance $(67 \%$ of the total analyzed products). On the other hand, 3-FMC and pentedrone were the main compounds in products 11 and 12, respectively. Also present, in product 12, was an isomeric impurity identified as isopentedrone (1-methylamino-1-phenylpentan-2-one), a by-product of the pentedrone synthesis, in which the amino moiety and keto group changed their position in the molecule. In relation to the adulterant compounds found in these products, caffeine was the most frequently detected substance ( $67 \%$ of the total analyzed products), followed by ethylphenidate ( $50 \%$ of the total analyzed products).

\subsection{NMR Analysis}

In order to complement the FTIR and GC-MS results, NMR analyzes were performed for a correct structural elucidation. The ${ }^{1} \mathrm{H}$ and ${ }^{13} \mathrm{C}$ NMR spectra of all substances were registered at 400 and $100 \mathrm{MHz}$, respectively. Signals assignments were based on chemical shifts $(\delta, \mathrm{ppm})$ of ${ }^{1} \mathrm{H}$ and ${ }^{13} \mathrm{C}$, on the multiplicity patterns of proton resonances depicted by the $J$ couplings $(\mathrm{Hz})$, and on data of homonuclear ${ }^{1} \mathrm{H}^{-1} \mathrm{H}$ COSY and heteronuclear ${ }^{1} \mathrm{H}^{-13} \mathrm{C}$ HMBC and HSQC. The NMR experiments and the signals assignments were made for all compounds and presented in Tables 3 and 4. For product 11, which contains a fluoromethcathinone, a ${ }^{19} \mathrm{~F}$ NMR spectrum $(376.5 \mathrm{MHz})$ was also recorded and the respective signal assignment was presented in Table 4 . For pyrovalerone derivatives, namely MPHP and $\alpha$-PHP, identified in products 1, and 2, respectively, the NMR spectra (Figures S4-S8, Supporting Information) showed many similarities, but also some differences that allowed unequivocal identification of both compounds. MPHP is a 1,4-disubstituted aromatic compound with a symmetric distribution of protons on the aromatic ring, and for this reason, the ${ }^{1} \mathrm{H}$ NMR signal of the aromatic protons exhibits a characteristic splitting pattern constituted by two doublets at $7.96 \mathrm{ppm}\left(\mathrm{H}-2^{\prime} / \mathrm{H}-6^{\prime}\right)$ and $7.47 \mathrm{ppm}\left(\mathrm{H}-3^{\prime} / \mathrm{H}-5^{\prime}\right)$. The methyl group attached to the para position of the benzene ring $\left(\mathrm{H}-\mathrm{7}^{\prime}\right)$ produced a large singlet at $2.46 \mathrm{ppm}$, which was also observed by Westphal et al. [44].

In contrast to MPHP, the ${ }^{1} \mathrm{H}$ NMR spectrum of $\alpha$-PHP showed a typical phenyl pattern at $7.65 \mathrm{ppm}$ (meta, appears as a $2 \mathrm{H}$ triplet), $7.81 \mathrm{ppm}$ (para, appears as a $1 \mathrm{H}$ triplet), and $8.06 \mathrm{ppm}$ (ortho, appears as a $2 \mathrm{H}$ doublet), which is consistent with the values reported in the literature $[45,46]$. The methine proton (H-2) of both pyrovalerone derivatives showed a triplet signal at around $5.3 \mathrm{ppm}$, and the protons of the alkyl side chain were found between $2.18 \mathrm{ppm}(\mathrm{H}-3)$ and $0.76 \mathrm{ppm}(\mathrm{H}-6)$. The multiplets of the methylene protons $\mathrm{H}-\mathrm{1}^{\prime \prime}$ and $\mathrm{H}-4^{\prime \prime}$ of the pyrrolidine-ring appeared as separated signals, centered at $3.07 \mathrm{ppm}\left({ }^{1} \mathrm{H}\right.$ from $\mathrm{H}-4$ " $)$, $3.36 \mathrm{ppm}\left({ }^{1} \mathrm{H}\right.$ from $\left.\mathrm{H}-1^{\prime \prime}\right)$ and $3.74 \mathrm{ppm}$ (two overlapped protons; ${ }^{1} \mathrm{H}$ from $\mathrm{H}-4$ " and $1 \mathrm{H}$ from $\mathrm{H}-1^{\prime \prime}$ ), while the proton signals of $\mathrm{H}-2^{\prime \prime}$ and $\mathrm{H}-3^{\prime \prime}$ appeared between 2.01 and $2.30 \mathrm{ppm}$ and were partially overlap with the methylene protons H-3 of the alkyl side chain. Due to their structural similarities, it was also possible to observe several common characteristics in the ${ }^{13} \mathrm{C}$ NMR spectra, including the signals for the carbon of the carbonyl group (C-1) around $198 \mathrm{ppm}$, the chiral carbon C-2 at $70 \mathrm{ppm}$ and the carbons of the aliphatic side chain C-3, C-4, C-5 and C-6 between $13.2 \mathrm{ppm}$ and $30.2 \mathrm{ppm}$. The carbons C-1" and C-4" of pyrrolidine moiety resonate at $52.6 \mathrm{ppm}$ and $55.8 \mathrm{ppm}$, respectively, while C-2" and C-3" signals are partially overlap at $23.3 \mathrm{ppm}$, in both compounds. The six aromatic carbons appearing as four signals for these pyrovalerone derivatives showed some differences, thus indicating chemical and structural differences between compounds. By the attachment of a substituent group to the benzene ring, the electronic density and consequently the chemical shifts of the carbon atoms will increase or decrease depending on the electronic nature of the substituent and its position in the aromatic ring [47]. In this sense, the presence of a methyl group in the para position of the aromatic ring of MPHP leads to a downfield shift of $12 \mathrm{ppm}$ of the $\mathrm{C}-4^{\prime}$ resonance in comparison with $\alpha$-PHP. In addition, the carbon of the methyl group C-7' attached to the aromatic ring produced a signal at around $21 \mathrm{ppm}$, which is in agreement with the results obtained by Westphal et al. [44]. 
Table 3. NMR assignments of SCat constituted by a pyrrolidine ring in the side chain or a methoxy or a methylenodioxy group attached to the aromatic ring.

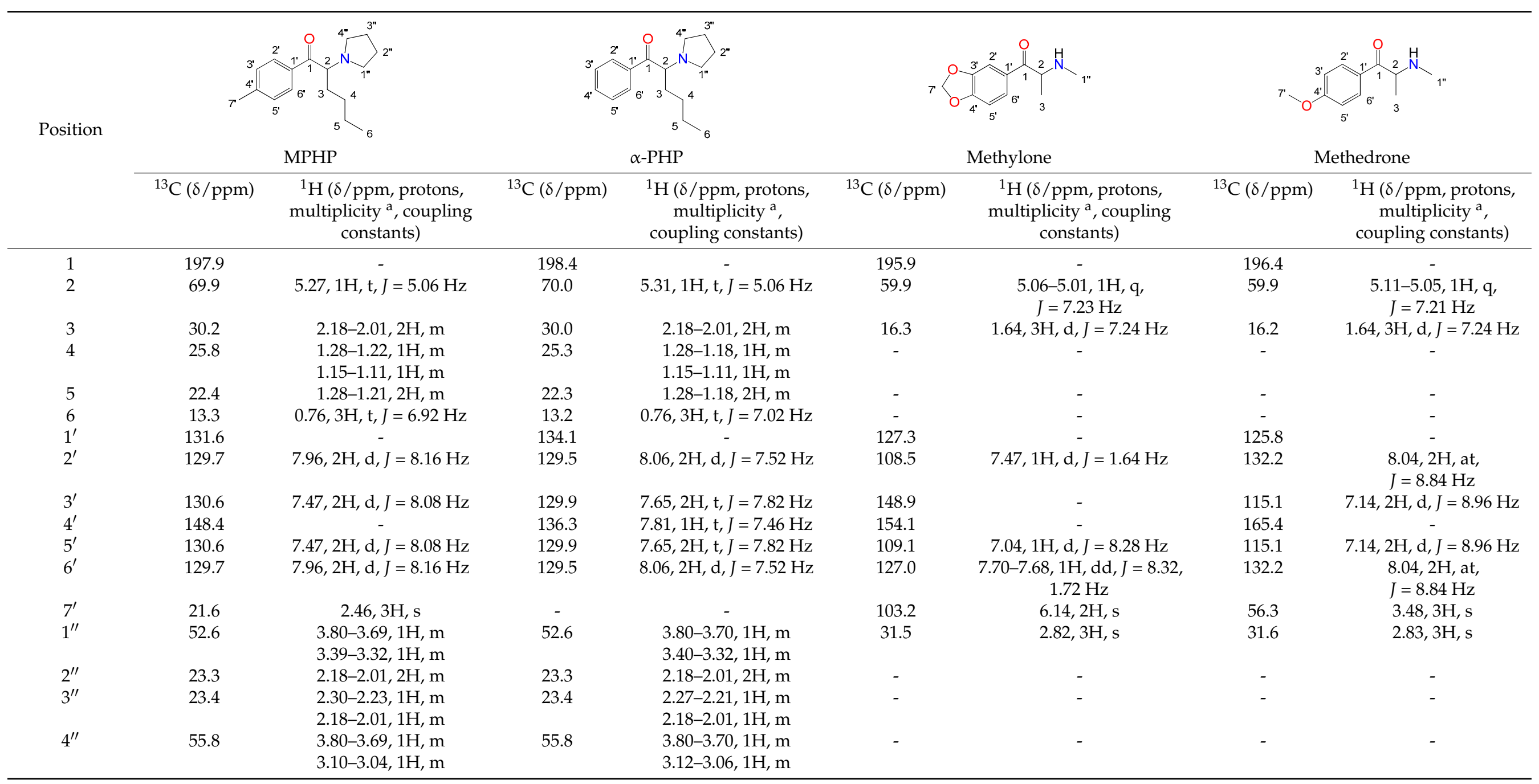

a abbreviations: $\mathrm{s}=$ singlet, $\mathrm{d}=$ doublet, $\mathrm{t}=$ triplet, $\mathrm{q}=$ quartet, $\mathrm{m}=$ multiplet, at $=$ apparent triplet, $\mathrm{dd}=$ doublet of doublets. $J=$ coupling constant. 
Table 4. NMR assignments of N-ethylcathinone, buphedrone, pentedrone and 3-FMC found in seized materials.

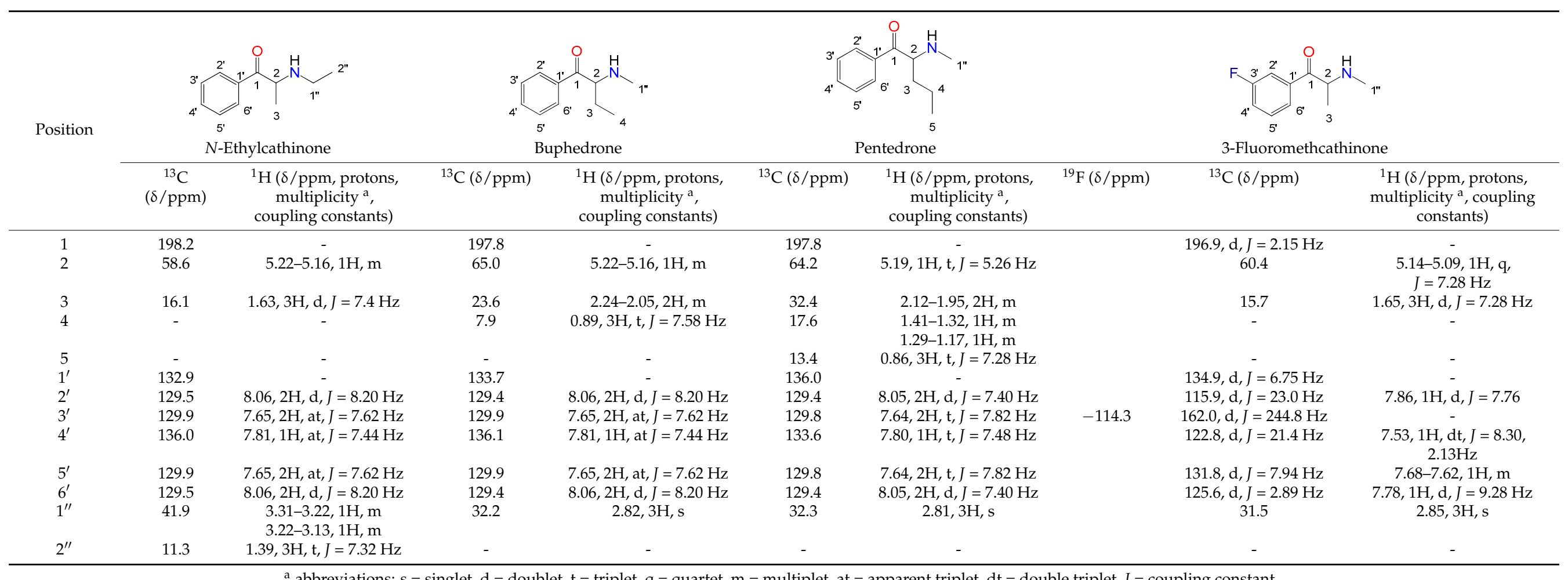

a abbreviations: $\mathrm{s}=$ singlet, $\mathrm{d}=$ doublet $\mathrm{t}=$ triplet $\mathrm{q}=$ quartet, $\mathrm{m}=$ multiplet, at $=$ apparent triplet, $\mathrm{dt}=$ double triplet,$J=$ coupling constant. 
For products 9 and 10, the NMR analysis confirmed the presence of methylone in both samples. Methylone is a 1,3,4-trisubstituted aromatic compound characterized by one double doublet at $7.70 \mathrm{ppm}\left(\mathrm{H}-6^{\prime}\right)$ and two doublets at $7.47\left(\mathrm{H}-2^{\prime}\right)$ and $7.04 \mathrm{ppm}\left(\mathrm{H}-5^{\prime}\right)$ on ${ }^{1} \mathrm{H}$ NMR spectrum. The methylenedioxy group attached to aromatic ring was identified by the singlet at $6.14 \mathrm{ppm}\left(\mathrm{H}-\mathrm{7}^{\prime}\right)$, while the methine proton $(\mathrm{H}-2)$ located between the carbonyl group and the nitrogen atom were observed at $5.06 \mathrm{ppm}$ (appears as a $1 \mathrm{H}$ quartet), which is in agreement with the results reported in the literature $[33,48,49]$. The singlet at 2.82 ppm integrates 3 protons and belongs to the $N$-methyl group $\left(\mathrm{H}-1^{\prime \prime}\right)$, while the doublet at $1.64 \mathrm{ppm}$ corresponds to the terminal methyl group of the alkyl side chain (H-3) that were confirmed by the COSY experiment (Figure 7). In the ${ }^{13} \mathrm{C}$ NMR spectrum the signals from the eleven carbon atoms were assigned based on two-dimensional experiments ${ }^{1} \mathrm{H}-{ }^{13} \mathrm{C}$ HSQC and HMBC (Figure 8). The carbon signals corresponding to the phenyl ring were observed at $108.5\left(\mathrm{C}-2^{\prime}\right), 109.1\left(\mathrm{C}-5^{\prime}\right), 127.0\left(\mathrm{C}-6^{\prime}\right), 127.3\left(\mathrm{C}-1^{\prime}\right), 148.9\left(\mathrm{C}-3^{\prime}\right)$ and $154.1 \mathrm{ppm}$ $\left(\mathrm{C}-4^{\prime}\right)$, while the methylenedioxy group $\left(\mathrm{C}-7^{\prime}\right)$ produced a signal at around $103 \mathrm{ppm}$. The carbonyl carbon (C-1) was found at 195.9 ppm, and the methine carbon (C-2) and the two methyl groups C-1" and C-3 appeared at 59.9, 31.5 and 16.3 ppm, respectively.

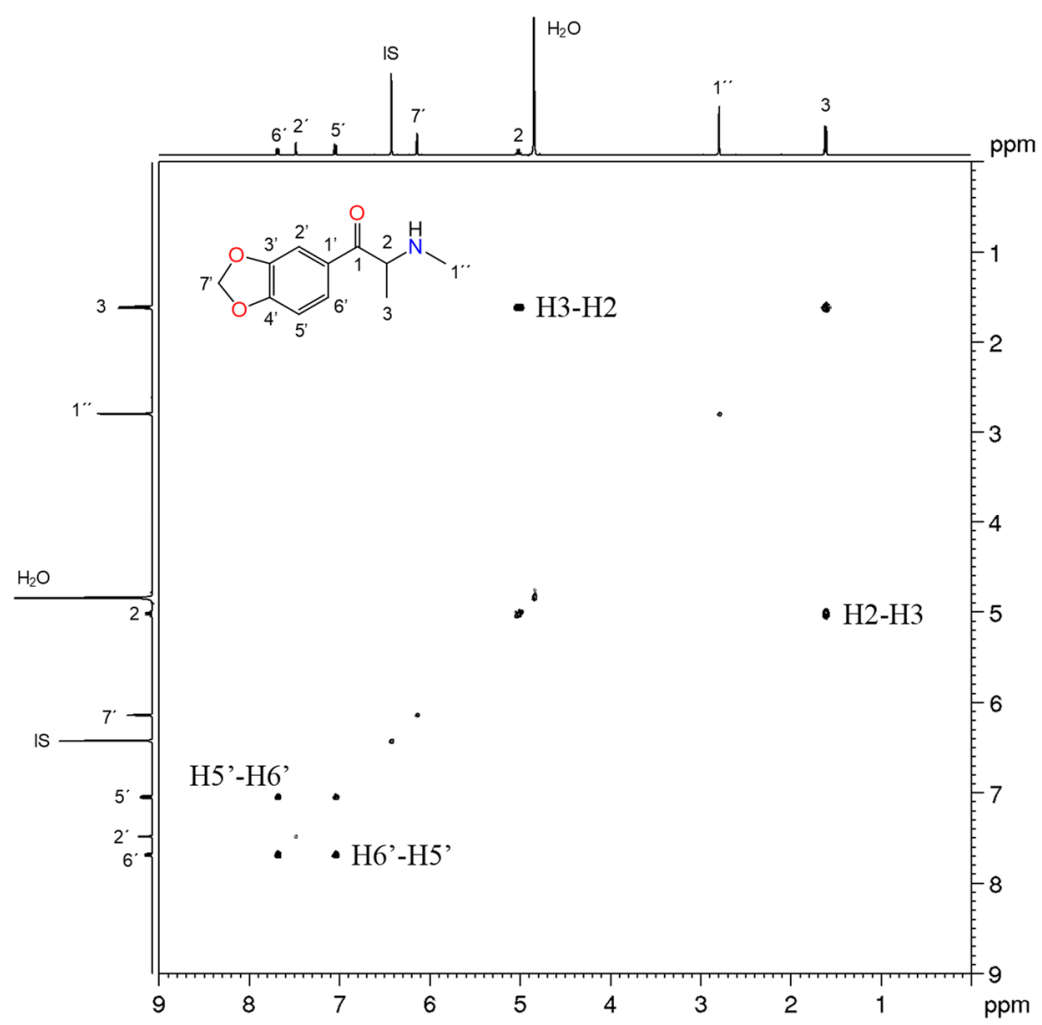

Figure 7. ${ }^{1} \mathrm{H}_{-}{ }^{1} \mathrm{H}$ COSY NMR spectrum of methylone found in product 10 .

Analytical data for products 3-7 revealed the presence of methedrone together with other cathinones, namely $N$-ethylcathinone and buphedrone. Methedrone is a methcathinone derivative only differing by the presence of a methoxy group in the para position of the aromatic ring. Hydrogens belonging to the methoxy group were identified in the ${ }^{1} \mathrm{H}$ NMR spectrum as a singlet at $3.48 \mathrm{ppm}$, while the proton attached to chiral carbon (H-2) was identified as a quartet at $5.11 \mathrm{ppm}$, which are in accordance with the results obtained by Zancajo et al. [50]. An apparent triplet at $8.04 \mathrm{ppm}$ (due to overlap with buphedrone and $N$-ethylcathinone signals) and a doublet at 7.14 ppm, with coupling constants of $8.84 \mathrm{~Hz}$ and $8.96 \mathrm{~Hz}$, supported substitution in para position. The methyl groups $\mathrm{H}-3$ and $\mathrm{H}-\mathrm{I}^{\prime \prime}$ produce a doublet at $1.64 \mathrm{ppm}$, and a singlet at $31.6 \mathrm{ppm}$, respectively. 

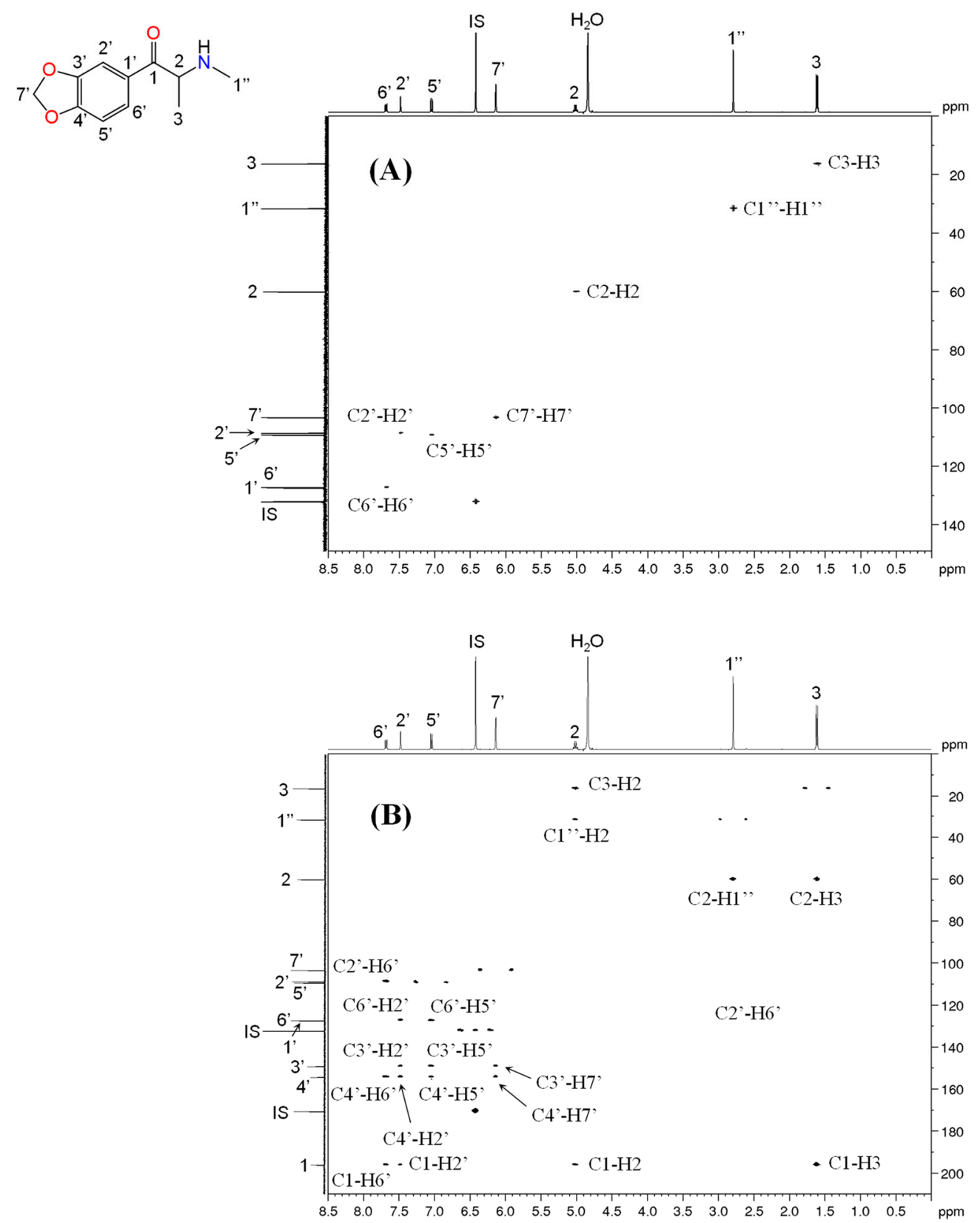

Figure 8. NMR spectra of methylone found in product 10 . (A) ${ }^{1} \mathrm{H}_{-}-{ }^{13} \mathrm{C} \mathrm{HSQC}$ and $(\mathbf{B}){ }^{1} \mathrm{H}_{-}{ }^{13} \mathrm{C} \mathrm{HMBC}$.

$\mathrm{N}$-Ethylcathinone and buphedrone have a close similar chemical structure, and for this reason, the protons corresponding to the aromatic ring were found overlapped. The protons in the ortho position ( $\mathrm{H}-2^{\prime}$ and $\left.\mathrm{H}-6^{\prime}\right)$ appeared as a doublet at $8.06 \mathrm{ppm}$ with a coupling constant of $8.20 \mathrm{~Hz}$, while meta $\left(\mathrm{H}-3^{\prime}\right.$ and $\left.\mathrm{H}-5^{\prime}\right)$ and para $\left(\mathrm{H}-4^{\prime}\right)$ protons appear as two apparent triplets at $7.65 \mathrm{ppm}$ and $7.81 \mathrm{ppm}$ with coupling constants of $7.62 \mathrm{~Hz}$ and $7.44 \mathrm{~Hz}$, respectively. As achieved by Zancajo et al. [50], both compounds showed the signal corresponding to the protons from chiral carbon atoms $(\mathrm{H}-2)$ overlapped and appeared as a multiplet at around $5.19 \mathrm{ppm}$. The $\mathrm{N}$-ethyl side chain of $\mathrm{N}$-ethylcathinone yielded two multiplets for methylene protons $\left(\mathrm{H}-1^{\prime \prime}\right)$ centered at $3.27 \mathrm{ppm}$ and $3.17 \mathrm{ppm}$ and one triplet for the terminal methyl group $\mathrm{H}-2^{\prime \prime}$ at $1.39 \mathrm{ppm}$, which are in agreement with the results obtained by Kuś et al. [51]. For buphedrone the $N$-methyl moiety resonates as a large singlet at $2.82 \mathrm{ppm}$, and the alkyl side chain presents a multiplet centered at $2.14 \mathrm{ppm}$ for the methylene protons $\mathrm{H}-3$ and a triplet at $0.89 \mathrm{ppm}$ for the terminal methyl group (H-4). 
In relation to product 12, the NMR data supported the previous findings of GC-MS and confirmed the presence of pentedrone. As expected, the ${ }^{1} \mathrm{H}$ NMR results obtained for this SCat was very similar to the ${ }^{1} \mathrm{H}$ NMR results for buphedrone, since both substances have similar chemical structures, differing only in the length of the alkyl chain. Pentedrone is constituted by only one more methylene group than buphedrone. The methinic proton of pentedrone was observed at $5.19 \mathrm{ppm}$ and the triplet is more defined than that verified for buphedrone. The two multiplets observed at 1.37 and $1.23 \mathrm{ppm}$ correspond to the diastereotopic protons $\mathrm{H}-4$, while the methylene protons $\mathrm{H}-3$ appeared at $2.04 \mathrm{ppm}$ as a multiplet. The protons corresponding to the terminal methyl group $\mathrm{H}-5$ remained relatively unchanged at around $0.86 \mathrm{ppm}$. Maheux and Copeland [29] obtained similar results during the chemical characterization of pentedrone and buphedrone in their study.

For product 11, the NMR analysis confirmed the presence of 3-FMC. The observed ${ }^{1} \mathrm{H}$ signals, relative to aliphatic portion of the 3-FMC, are similar to those observed for methedrone and methylone. However, the signals pattern observed in the aromatic region was distinct from these previous ones. The two doublets observed at $7.86 \mathrm{ppm}$ and $7.78 \mathrm{ppm}$ corresponded to the protons at ortho position $\mathrm{H}-2^{\prime}$ and $\mathrm{H}-6^{\prime}$, respectively, while the multiplet centred at $7.65 \mathrm{ppm}$ and the double triplet at $7.53 \mathrm{ppm}$ belonged to the protons in the meta $\left(\mathrm{H}-5^{\prime}\right)$ and para $\left(\mathrm{H}-4^{\prime}\right)$ positions. Moreover, the doublet splitting of the carbon atom signals at position $1^{\prime}$ to $6^{\prime}$ and the spin-spin coupling constants $\left({ }^{1} J_{\mathrm{C} 3^{\prime}-\mathrm{F}}=244.8 \mathrm{~Hz}\right.$, $\left.{ }^{2} J_{\mathrm{C}^{\prime}-\mathrm{F}}=23.0 \mathrm{~Hz},{ }^{2} J_{\mathrm{C} 4^{\prime}-\mathrm{F}}=21.4 \mathrm{~Hz},{ }^{3} J_{\mathrm{C}^{\prime}-\mathrm{F}}=7.94 \mathrm{HZ},{ }^{3} J_{\mathrm{Cl}^{\prime}-\mathrm{F}}=6.75 \mathrm{~Hz},{ }^{4} J_{\mathrm{C} 6^{\prime}-\mathrm{F}}=2.89 \mathrm{~Hz}\right)$ were characteristic for fluorine-carbon interactions, which supported the assignment of the $3^{\prime}$-position for the fluorine atom [52]. On the other hand, the ${ }^{19} \mathrm{~F} N \mathrm{NR}$ chemical shift value for the 3 -FMC was $-114.3 \mathrm{ppm}$, which is close related with the reported in the literature [52].

Regarding to the purity of these products, Figure 9 shows the mass fraction $(\% \mathrm{~m} / \mathrm{m})$ of each compound found in the seized products. Some of the analyzed products only present one active principle (e.g., product 1, 2 and 10), while most of them are mixtures of psychoactive substances with a high number of constituents, as for example products 3-7 ("Bloom") or product 12 ("Kick").

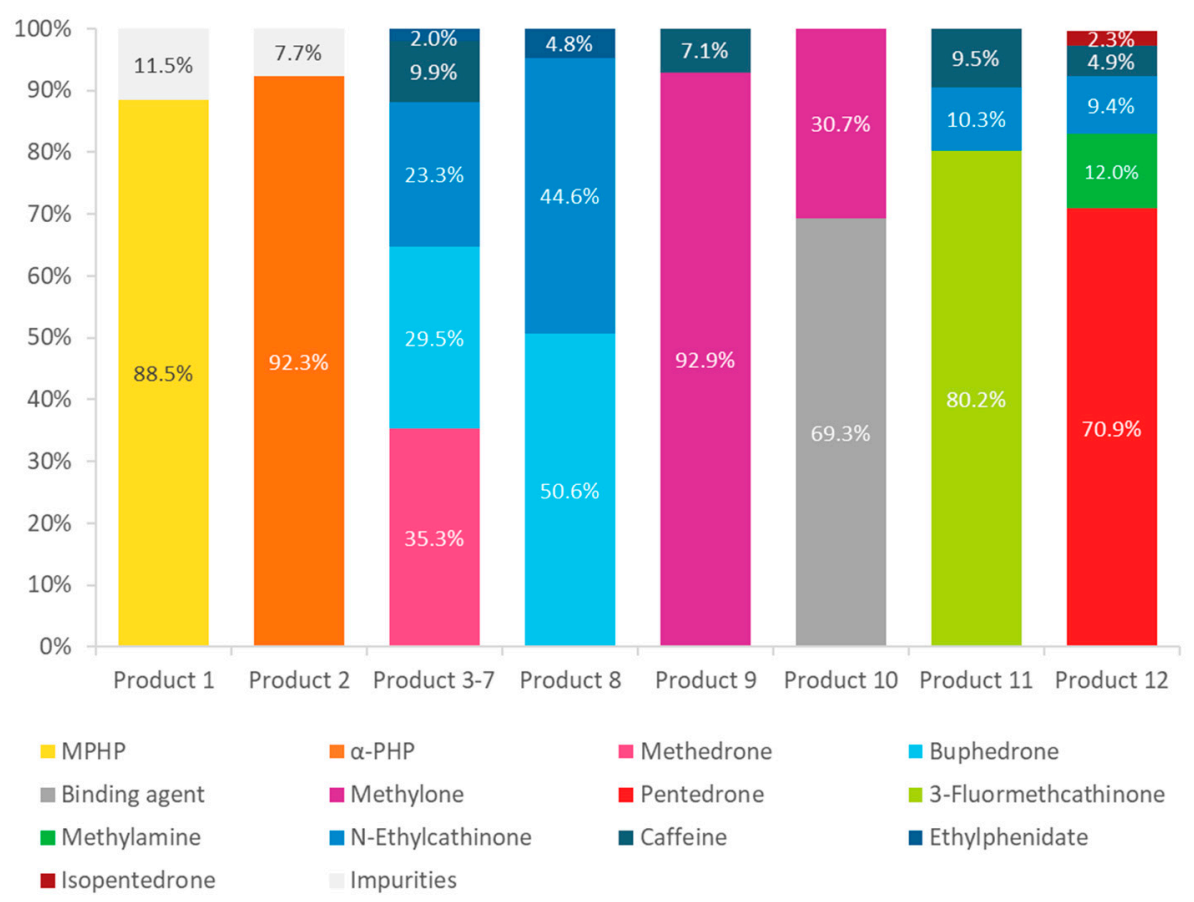

Figure 9. Relative proportions of active substances detected in 12 seized products.

As verified by GC-MS, caffeine and ethylphenidate were the main adulterants found in these samples. The respective assignments of ${ }^{1} \mathrm{H}$ and ${ }^{13} \mathrm{C}$ signals are described in 
Table S1 (Supplementary Information). The presence of isopentedrone in product 12 was also confirmed by NMR, being this the minor compound found in this product $(2.3 \%)$. Additionally, in the same product, NMR analysis allowed the identification of methylamine, which is commonly used in the synthesis of $N$-methyl cathinones and is not detected in the GC-MS analysis due to its volatility [5]. The presence of methylamine in these products was not surprising, since it was previously reported in other works $[5,52]$.

For product 10 , only $31 \%$ of the analyzed tablets contained methylone in their composition. In fact, during the preparation of this sample for GC-MS and NMR analysis, an insoluble material was observed and was removed from the solution through filtration, and then analyzed by ATR-FTIR. The results are present in Figure S9 (Supporting Information) and the substance was identified as microcrystalline cellulose, which probably was used as a binding agent for direct tablet compression or even added to increase the amount of substance (bulking agent) [53].

\section{Materials and Methods}

\subsection{Reagents}

All used chemicals were of analytical grade. Methanol was obtained from Fisher Chemicals (Loures, Portugal), while ethyl acetate was provided by Riedel-de Haën (Seelze, Germany). Trifluoroacetic anhydride (TFAA $\geq 99.0 \%$ ), maleic acid $(99.0 \%)$, trifluoroacetic acid (TFA, 99.0\%) and deuterium oxide (99.9\%) were obtained from Sigma-Aldrich (St. Louis, MO, USA), while pure caffeine was purchased from Merck (Darmstadt, Germany).

\subsection{Samples}

Twelve seized products suspected to contain illicit substances were provided by the Forensic Science Laboratory of Portuguese Criminal Police, under a special authorization. The products were presented in different forms, including powders, crystals and tablets, packed in small plastic bags with striking designs or, occasionally, in transparent plastic bags. Some of the products were labelled as "plant feeders" with the indication "not for human consumption". Table 1 shows the list of provided substances, with the respective information about their composition indicated on the product label.

\subsection{ATR-FTIR Analysis}

A PerkinElmer ${ }^{\circledR}$ Spectrum Two FTIR Spectrometer (Waltham, MA, USA) equipped with a DuraSamplIR ${ }^{\mathrm{TM}}$ diamond ATR unit (Smiths Detection, London, UK) was used for infrared spectroscopy analysis. Approximately $20 \mathrm{mg}$ of powder sample was placed on the small ATR crystal area, and the infrared spectra were collected in the range from 4000 to $600 \mathrm{~cm}^{-1}$, with 32 scans at $4 \mathrm{~cm}^{-1}$ resolution. Spectra were obtained in triplicate and a PerkinElmer Spectrum IR software, version 10.6.0, was used for processing and visualizing the spectra.

\subsection{GC-MS Analysis}

For GC-MS analysis, each sample was homogenized and dissolved in methanol to a final concentration of $1 \mathrm{mg} \mathrm{mL}^{-1}$. Before the GC-MS analysis, each solution was filtered through $0.22 \mu \mathrm{m}$ polytetrafluoroethylene (PTFE) membrane filters (Millipore, Milford, MA, USA) and $2 \mu \mathrm{L}$ of sample were directly injected into the GC-MS. Derivatization with TFAA was also performed according to the method developed by Araújo et al. [5] with some modifications. Each sample was prepared to a final concentration of $100 \mu \mathrm{g} \mathrm{mL}^{-1}$ by dilution of the initial methanolic solution $\left(1 \mathrm{mg} \mathrm{mL}^{-1}\right)$ and was evaporated to dryness under nitrogen flow. Then $100 \mu \mathrm{L}$ of TFAA/ethyl acetate $(1: 1, v / v)$ was added to the dried residue and the incubation was performed at $70{ }^{\circ} \mathrm{C}$ for $30 \mathrm{~min}$. After cooling to room temperature, the solvent was evaporated to dryness under a nitrogen stream, and the residues were reconstituted in $100 \mu \mathrm{L}$ of ethyl acetate. A $2 \mu \mathrm{L}$ aliquot of the resulting solution was injected into the GC-MS system. 
GC-MS analysis was performed with an Agilent 6890N GC system (Palo Alto, CA, USA) equipped with a 5975 Mass Selective Detector (Agilent Technologies, Palo Alto, CA, USA). The samples were separated using an Agilent J\&W HP-5 capillary column (30 $\mathrm{m} \times 0.32 \mathrm{~mm}$ ID, $0.25 \mu \mathrm{m}$ film thickness), and helium (Air Liquid, Alges, Portugal) was used as the carrier gas, at a constant flow of $1.3 \mathrm{~mL} \mathrm{~min}^{-1}$. The injections were performed in split mode, with a ratio of 40:1. The injector port was heated to $250{ }^{\circ} \mathrm{C}$ and $2 \mu \mathrm{L}$ of sample was injected in the GC system. The initial column temperature was set to $60^{\circ} \mathrm{C}$ for $4 \mathrm{~min}$, followed by a temperature ramp of $15^{\circ} \mathrm{C} \mathrm{min}-1$ to $150{ }^{\circ} \mathrm{C}$, held for $5 \mathrm{~min}$, and $20^{\circ} \mathrm{C}$ $\mathrm{min}^{-1}$ to $290^{\circ} \mathrm{C}$ held for $10 \mathrm{~min}$. The mass spectrometer was operated in electron impact ionization (EI) mode at $70 \mathrm{eV}$. For the MS system, the temperatures of the transfer line, quadrupole and ionization source were 250,150 , and $230^{\circ} \mathrm{C}$, respectively. The ionization was maintained off during the first $4 \mathrm{~min}$, to avoid solvent overloading. The mass spectra were recorded in range of 40-500 m/z and acquisition was made in Full Scan mode, with a scan rate of 6 scans/s. All mass spectra were compared with NIST 14 MS library and SWGDRUG MS library version 3.4.

\subsection{NMR Analysis}

For NMR analysis, $10 \mathrm{mg}$ of sample was dissolved in $500 \mu \mathrm{L}$ of deuterium oxide $\left(\mathrm{D}_{2} \mathrm{O}\right)$ containing maleic acid as the internal standard $\left(5 \mathrm{mg} \mathrm{mL}^{-1}\right)$. The resulting mixture was transferred to a $5 \mathrm{~mm}$ NMR tube and the NMR spectra were acquired in a Brucker Avance II $400 \mathrm{MHz}$ Spectrometer (Bruker BioSpin GmbH, Rheinstetten, Germany), operating at $400.13 \mathrm{MHz}$ for ${ }^{1} \mathrm{H}$ NMR and $100.61 \mathrm{MHz}$ for ${ }^{13} \mathrm{C}$ NMR. Chemical shifts $(\delta)$ were expressed as parts per million (ppm) and referenced to the signal of maleic acid $(\delta \mathrm{H}=6.42$, $\delta C=132.16)$. Coupling constants $(J)$ were reported in units of Hertz $(\mathrm{Hz})$. Structure elucidation by respective assignment of the carbon and proton signals was based on the analysis of NMR spectra obtained by $1 \mathrm{D}\left({ }^{1} \mathrm{H}\right.$ and $\left.{ }^{13} \mathrm{C}\right)$ and 2D (COSY, HMBC and HSQC) techniques. For product $11, \mathrm{a}{ }^{19} \mathrm{~F}$ NMR spectrum $(376.5 \mathrm{MHz})$ was also recorded, and the chemical shifts were referenced to the TFA resonance at $-78 \mathrm{ppm}$.

For NMR purity assessment, the ${ }^{1} \mathrm{H}$ signal integration for each compound was calculated calibrating for 100 the area of maleic acid resonance peak. The purity of the products was assessed calculating the mass fraction $(\% \mathrm{~m} / \mathrm{m})$ of each compound in the seized products, using the following equation,

$$
\text { \%compound }=\frac{I_{X}}{I_{I S}} \times \frac{N_{I S}}{N_{X}} \times \frac{M_{X}}{M_{I S}} \times \frac{m_{I S}}{m_{\text {sample }}} \times P_{I S}
$$

where $I_{X}$ and $I_{I S}$ are the integrated area of the compound of interest $(X)$ and the internal standard (IS), $N_{X}$ and $N_{I S}$ are the numbers of protons generating the selected signals for integration, $M_{X}$ and $M_{I S}$ are the molecular weights in $\mathrm{g} \mathrm{mol}^{-1}, m_{\text {sample }}$ and $m_{I S}$ are the masses of the sample and the internal standard, respectively, and $P_{I S}$ is the purity of maleic acid.

\section{Conclusions}

The present study describes the identification of 8 SCat as the key constituents found in 12 seized products. In general, the products showed different compositions between them, although very similar for the products labelled with the same name. Among the identified SCat, six of them, methylone, methedrone, $N$-ethylcathinone, buphedrone, pentedrone and 3-FMC, belong to the "classic cathinone group", analogues of amphetamines, being considered as the first generation of SCat. Pyrovalerone derivatives, a particular class of SCat, characterized by the presence of a pyrrolidine ring in their chemical structures, were also identified in two distinct products with a high degree of purity. MPHP was found in product 1 with a purity of $89 \%$, while $\alpha$-PHP was found in product 2 with a purity of $92 \%$. Among the adulterants, caffeine, an active ingredient commonly found in illicit drugs, was the most frequently detected substance ( $67 \%$ of the total analyzed products), followed by 
ethylphenidate ( $50 \%$ of the total analyzed products). Both substances are probably added to these products, since they are cheap and potentiate the stimulating effect.

In relation to the analytical techniques, the combination of ATR-FTIR, GC-MS and NMR techniques proved to be an effective methodology to unequivocally identify the molecular structure of the SCat present in "plant feeders", even in the absence of certified standards. While ATR-FTIR provided a quick and presumptive identification of the seized drugs without destroying evidence, the GC-MS allowed the precise identification of the substances, being an excellent tool for confirmatory tests. On the other hand, NMR spectroscopy proved to be of great importance for structural elucidation allowing the positional isomers distinction, and the identification of compounds not detected in the GC-MS, such as methylamine.

Supplementary Materials: The following are available online at https://www.mdpi.com/2218-1 989/11/3/144/s1, Figure S1: FTIR spectra of seized products suspected to contain SCat, Figure S2: Typical GC-MS chromatograms of seized products suspected to contain SCat, Figure S3: Typical GC-MS chromatograms of seized products after derivatization with TFAA, Figure S4: ${ }^{1} \mathrm{H}$ NMR spectra of seized products, Figure S5: ${ }^{13} \mathrm{C}$ NMR spectra of seized products, Figure S6: ${ }^{1} \mathrm{H}-{ }^{1} \mathrm{H}$ COSY NMR spectra of MPHP and $\alpha$-PHP found in products 1 and 2, respectively, Figure S7: ${ }^{1} \mathrm{H}^{-13} \mathrm{C}$ HSQC and HMBC NMR spectra of MPHP found in product 1, Figure S8: ${ }^{1} \mathrm{H}-{ }^{13} \mathrm{C}$ HSQC and HMBC NMR spectra of $\alpha$-PHP found in product 2, Figure S9: FTIR spectra of the insoluble substance found in product 10, Table S1: ${ }^{1} \mathrm{H}$ and ${ }^{13} \mathrm{C}$ NMR assignments of adulterants found in seized materials.

Author Contributions: Conceptualization, J.S.C. and H.M.T.; methodology, J.L.G., V.L.A. and J.A.; investigation, J.L.G., V.L.A. and J.A.; data curation, J.L.G., V.L.A. and J.A.; writing-original draft preparation, J.L.G., V.L.A. and J.A.; resources, M.J.C. and J.S.C.; supervision, H.M.T., J.S.C. and M.J.C.; writing - review and editing, H.M.T. and J.S.C.; project administration, J.S.C.; funding acquisition, J.S.C. All authors have read and agreed to the published version of the manuscript.

Funding: This work was supported by Fundação para a Ciência e a Tecnologia through Centro de Química da Madeira Base Fund (UIDB/00674/2020, and Programmatic Fund-UIDP /00674/2020) and the PhD fellowships (SFRH/BD/116895/2016 and SFRH/BD/117426/2016) granted to João L. Gonçalves and Vera L. Alves and through Madeira 14-20 Program, project PROEQUIPRAM-Reforço do Investimento em Equipamentos e Infraestruturas Científicas na RAM (M1420-01-0145-FEDER000008), and by ARDITI-Agência Regional para o Desenvolvimento da Investigação Tecnologia e Inovação, through the project M1420-01-0145-FEDER-000005-Centro de Química da Madeira-CQM+ (Madeira 14-20 Program).

Institutional Review Board Statement: Not applicable.

Informed Consent Statement: Not applicable.

Data Availability Statement: No new data were created or analyzed in this study. Data sharing is not applicable to this article.

Acknowledgments: The authors would like to thank the Forensic Science Laboratory of Portuguese Criminal Police for their collaboration in providing the seized products.

Conflicts of Interest: The authors declare no conflict of interest.

\section{References}

1. Gonçalves, J.L.; Alves, V.L.; Aguiar, J.; Teixeira, H.M.; Câmara, J.S. Synthetic cathinones: An evolving class of new psychoactive substances. Crit. Rev. Toxicol. 2019, 49, 549-566. [CrossRef]

2. EURAD. Psychoactive Substances: Issues for Policy Makers. Available online: https://www.unodc.org/documents/ungass2016/ Contributions/Civil/EURAD/Psychoactive_Substances_Exec_Summary.pdf (accessed on 4 December 2019).

3. EMCDDA. European Drug Report 2017: Trends and Developments. Available online: https://www.emcdda.europa.eu/ publications/edr/trends-developments/2017_en (accessed on 22 October 2019).

4. Gavriilidis, G.; Kyriakoudi, A.; Tiniakos, D.; Rovina, N.; Koutsoukou, A. "Bath Salts" intoxication with multiorgan failure and left-sided ischemic colitis: A case report. Hippokratia 2015, 19, 363-365. [PubMed]

5. Araújo, A.M.; Valente, M.J.; Carvalho, M.; Dias da Silva, D.; Gaspar, H.; Carvalho, F.; de Lourdes Bastos, M.; Guedes de Pinho, P. Raising awareness of new psychoactive substances: Chemical analysis and in vitro toxicity screening of 'legal high' packages containing synthetic cathinones. Arch. Toxicol. 2015, 89, 757-771. [CrossRef] 
6. Meyers, K.; Kaynak, Ö.; Bresani, E.; Curtis, B.; McNamara, A.; Brownfield, K.; Kirby, K.C. The availability and depiction of synthetic cathinones (bath salts) on the Internet: Do online suppliers employ features to maximize purchases? Int. J. Drug Policy 2015, 26, 670-674. [CrossRef]

7. Valente, M.J.; Guedes de Pinho, P.; Bastos, M.d.L.; Carvalho, F.; Carvalho, M. Khat and synthetic cathinones: A review. Arch. Toxicol. 2014, 88, 15-45. [CrossRef]

8. Valente, M.J.; Araújo, A.M.; Bastos, M.d.L.; Fernandes, E.; Carvalho, F.; Guedes de Pinho, P.; Carvalho, M. Editor's Highlight: Characterization of Hepatotoxicity Mechanisms Triggered by Designer Cathinone Drugs ( $\beta$-Keto Amphetamines). Toxicol. Sci. 2016, 153, 89-102. [CrossRef]

9. Majchrzak, M.; Celiński, R.; Kuś, P.; Kowalska, T.; Sajewicz, M. The newest cathinone derivatives as designer drugs: An analytical and toxicological review. Forensic Toxicol. 2018, 36, 33-50. [CrossRef]

10. Prosser, J.M.; Nelson, L.S. The Toxicology of Bath Salts: A Review of Synthetic Cathinones. J. Med. Toxicol. 2012, 8, 33-42. [CrossRef] [PubMed]

11. Schifano, F.; Papanti, G.D.; Orsolini, L.; Corkery, J.M. Novel psychoactive substances: The pharmacology of stimulants and hallucinogens. Expert Rev. Clin. Pharmacol. 2016, 9, 943-954. [CrossRef]

12. Calinski, D.M.; Kisor, D.F.; Sprague, J.E. A review of the influence of functional group modifications to the core scaffold of synthetic cathinones on drug pharmacokinetics. Psychopharmacology 2019, 236, 881-890. [CrossRef]

13. Zawilska, J.B.; Andrzejczak, D. Next generation of novel psychoactive substances on the horizon-A complex problem to face. Drug Alcohol Depend. 2015, 157, 1-17. [CrossRef]

14. Archer, T.; Kostrzewa, R.M. Synthetic Cathinones: Neurotoxic Health Hazards and Potential for Abuse. In Synthetic Cathinones: Novel Addictive and Stimulatory Psychoactive Substances; Zawilska, J.B., Ed.; Springer International Publishing: Cham, Switzerland, 2018; pp. 1-10.

15. Karila, L.; Megarbane, B.; Cottencin, O.; Lejoyeux, M. Synthetic Cathinones: A New Public Health Problem. Curr. Neuropharmacol. 2015, 13, 12-20. [CrossRef] [PubMed]

16. Van Hout, M.C.; Bingham, T. "A Costly Turn On”: Patterns of use and perceived consequences of mephedrone based head shop products amongst Irish injectors. Int. J. Drug Policy 2012, 23, 188-197. [CrossRef]

17. Spiller, H.A.; Ryan, M.L.; Weston, R.G.; Jansen, J. Clinical experience with and analytical confirmation of "bath salts" and "legal highs" (synthetic cathinones) in the United States. Clin. Toxicol. 2011, 49, 499-505. [CrossRef]

18. Barrios, L.; Grison-Hernando, H.; Boels, D.; Bouquie, R.; Monteil-Ganiere, C.; Clement, R. Death following ingestion of methylone. Int. J. Leg. Med. 2016, 130, 381-385. [CrossRef] [PubMed]

19. Zaami, S.; Giorgetti, R.; Pichini, S.; Pantano, F.; Marinelli, E.; Busardò, F.P. Synthetic cathinones related fatalities: An update. Eur. Rev. Med Pharmacol. Sci. 2018, 22, 268-274. [PubMed]

20. Romanek, K.; Stenzel, J.; Schmoll, S.; Schrettl, V.; Geith, S.; Eyer, F.; Rabe, C. Synthetic cathinones in Southern Germanycharacteristics of users, substance-patterns, co-ingestions, and complications. Clin. Toxicol. 2017, 55, 573-578. [CrossRef] [PubMed]

21. Palamar, J.J.; Salomone, A.; Vincenti, M.; Cleland, C.M. Detection of "bath salts" and other novel psychoactive substances in hair samples of ecstasy/MDMA/“Molly" users. Drug Alcohol Depend. 2016, 161, 200-205. [CrossRef]

22. Wojcieszak, J.; Andrzejczak, D.; Wojtas, A.; Gołembiowska, K.; Zawilska, J.B. Effects of the new generation $\alpha$-pyrrolidinophenones on spontaneous locomotor activities in mice, and on extracellular dopamine and serotonin levels in the mouse striatum. Forensic Toxicol. 2018, 36, 334-350. [CrossRef] [PubMed]

23. Assi, S.; Guirguis, A.; Halsey, S.; Fergus, S.; Stair, J.L. Analysis of 'legal high' substances and common adulterants using handheld spectroscopic techniques. Anal. Methods 2015, 7, 736-746. [CrossRef]

24. Majchrzak, M.; Celiński, R.; Kowalska, T.; Sajewicz, M. Fatal case of poisoning with a new cathinone derivative: $\alpha-$ propylaminopentiophenone (N-PP). Forensic Toxicol. 2018, 36, 525-533. [CrossRef]

25. DRE. Decree Law No. 54/2013 of 17 April 2013, Administrative Rule 154/2013. Available online: https:/ / dre.pt/pesquisa/- / search/260421/details/ (accessed on 24 July 2020).

26. Liu, C.; Jia, W.; Li, T.; Hua, Z.; Qian, Z. Identification and analytical characterization of nine synthetic cathinone derivatives $\mathrm{N}$-ethylhexedrone, 4-Cl-pentedrone, 4-Cl- $\alpha$-EAPP, propylone, N-ethylnorpentylone, 6-MeO-bk-MDMA, $\alpha$-PiHP, 4-Cl- $\alpha$-PHP, and 4-F- $\alpha$-PHP. Drug Test. Anal. 2017, 9, 1162-1171. [CrossRef] [PubMed]

27. Antunes, M.; Sequeira, M.; de Caires Pereira, M.; Caldeira, M.J.; Santos, S.; Franco, J.; Barroso, M.; Gaspar, H. Determination of Selected Cathinones in Blood by Solid-Phase Extraction and GC-MS. J. Anal. Toxicol. 2020, 1-10. [CrossRef] [PubMed]

28. Carlsson, A.; Sandgren, V.; Svensson, S.; Konradsson, P.; Dunne, S.; Josefsson, M.; Dahlén, J. Prediction of designer drugs: Synthesis and spectroscopic analysis of synthetic cathinone analogs that may appear on the Swedish drug market. Drug Test. Anal. 2018, 10, 1076-1098. [CrossRef] [PubMed]

29. Maheux, C.R.; Copeland, C.R. Chemical analysis of two new designer drugs: Buphedrone and pentedrone. Drug Test. Anal. 2012, 4, 17-23. [CrossRef]

30. Maheux, C.R.; Alarcon, I.Q.; Copeland, C.R.; Cameron, T.S.; Linden, A.; Grossert, J.S. Identification of polymorphism in ethylone hydrochloride: Synthesis and characterization. Drug Test. Anal. 2016, 8, 847-857. [CrossRef]

31. Westphal, F.; Junge, T.; Girreser, U.; Greibl, W.; Doering, C. Mass, NMR and IR spectroscopic characterization of pentedrone and pentylone and identification of their isocathinone by-products. Forensic Sci. Int. 2012, 217, 157-167. [CrossRef] 
32. Smith, B.C. Infrared Spectral Interpretation: A Systematic Approach; Taylor \& Francis: New York, NY, USA, 1998.

33. Kavanagh, P.; O’Brien, J.; Fox, J.; O’Donnell, C.; Christie, R.; Power, J.D.; McDermott, S.D. The analysis of substituted cathinones. Part 3. Synthesis and characterisation of 2,3-methylenedioxy substituted cathinones. Forensic Sci. Int. 2012, 216, 19-28. [CrossRef]

34. Coates, J. Interpretation of Infrared Spectra, A Practical Approach. In Encyclopedia of Analytical Chemistry; Meyers, R.A., McKelvy, M.L., Eds.; John Wiley \& Sons: New York, NY, USA, 2006.

35. Zuba, D. Identification of cathinones and other active components of 'legal highs' by mass spectrometric methods. Trac Trends Anal. Chem. 2012, 32, 15-30. [CrossRef]

36. Kohyama, E.; Chikumoto, T.; Tada, H.; Kitaichi, K.; Horiuchi, T.; Ito, T. Differentiation of the Isomers of N-Alkylated Cathinones by GC-EI-MS-MS and LC-PDA. Anal. Sci. Int. J. Jpn. Soc. Anal. Chem. 2016, 32, 831-837. [CrossRef]

37. Paillet-Loilier, M.; Cesbron, A.; Le Boisselier, R.; Bourgine, J.; Debruyne, D. Emerging drugs of abuse: Current perspectives on substituted cathinones. Subst. Abus. Rehabil. 2014, 5, 37-52. [CrossRef]

38. Gwak, S.; Arroyo-Mora, L.E.; Almirall, J.R. Qualitative analysis of seized synthetic cannabinoids and synthetic cathinones by gas chromatography triple quadrupole tandem mass spectrometry. Drug Test. Anal. 2015, 7, 121-130. [CrossRef]

39. Lum, B.J.; Hibbert, D.B.; Brophy, J. Identification of Substituted Cathinones ( $\beta$-keto phenethylamines) by Heptafluorobutyric Anhydride (HFBA) Chemical Derivatization and Gas Chromatography Mass Spectrometry. Swafs J. 2013, 34, 7-30.

40. Moldoveanu, S.C.; David, V. Derivatization Methods in GC and GC/MS. In Gas Chromatography-Derivatization, Sample Preparation, Application; Kusch, P., Ed.; IntechOpen: London, UK, 2018.

41. Kumazawa, T.; Hara, K.; Hasegawa, C.; Uchigasaki, S.; Lee, X.-P.; Seno, H.; Suzuki, O.; Sato, K. Fragmentation Pathways of Trifluoroacetyl Derivatives of Methamphetamine, Amphetamine, and Methylenedioxyphenylalkylamine Designer Drugs by Gas Chromatography/Mass Spectrometry. Int. J. Spectrosc. 2011, 2011, 318148. [CrossRef]

42. Alsenedi, K.A.; Morrison, C. Comparison of six derivatizing agents for the determination of nine synthetic cathinones using gas chromatography-mass spectrometry. Anal. Methods 2017, 9, 2732-2743. [CrossRef]

43. Ash, J.; Hickey, L.; Goodpaster, J. Formation and identification of novel derivatives of primary amine and zwitterionic drugs. Forensic Chem. 2018, 10, 37-47. [CrossRef]

44. Westphal, F.; Junge, T.; Rösner, P.; Fritschi, G.; Klein, B.; Girreser, U. Mass spectral and NMR spectral data of two new designer drugs with an $\alpha$-aminophenone structure: $4^{\prime}$-Methyl- $\alpha$-pyrrolidinohexanophenone and $4^{\prime}$-methyl- $\alpha$-pyrrolidinobutyrophenone. Forensic Sci. Int. 2007, 169, 32-42. [CrossRef]

45. Majchrzak, M.; Rojkiewicz, M.; Celiński, R.; Kuś, P.; Sajewicz, M. Identification and characterization of new designer drug 4-fluoro-PV9 and $\alpha$-PHP in the seized materials. Forensic Toxicol. 2016, 34, 115-124. [CrossRef]

46. Uchiyama, N.; Shimokawa, Y.; Kawamura, M.; Kikura-Hanajiri, R.; Hakamatsuka, T. Chemical analysis of a benzofuran derivative, 2-(2-ethylaminopropyl)benzofuran (2-EAPB), eight synthetic cannabinoids, five cathinone derivatives, and five other designer drugs newly detected in illegal products. Forensic Toxicol. 2014, 32, 266-281. [CrossRef]

47. Balci, M. ${ }^{13} \mathrm{C}$ Chemical Shifts of Organic Compounds; Elsevier Science: Amsterdam, The Netherlands, 2005.

48. Souza, L.F.; Vieira, T.S.; Alcantara, G.B.; Lião, L.M. HR-MAS NMR for Rapid Identification of Illicit Substances in Tablets and Blotter Papers Seized by Police Department. J. Braz. Chem. Soc. 2016, 27, 2141-2148. [CrossRef]

49. Maheux, C.R.; Copeland, C.R.; Pollard, M.M. Characterization of Three Methcathinone Analogs: 4-Methylmethcathinone, Methylone, and bk-MBDB. Microgram J. 2010, 7, 42-49.

50. Zancajo, V.M.R.; Brito, J.; Carrasco, M.P.; Bronze, M.R.; Moreira, R.; Lopes, A. Analytical profiles of "legal highs" containing cathinones available in the area of Lisbon, Portugal. Forensic Sci. Int. 2014, 244, 102-110. [CrossRef] [PubMed]

51. Kuś, P.; Kusz, J.; Książek, M.; Pieprzyca, E.; Rojkiewicz, M. Spectroscopic characterization and crystal structures of two cathinone derivatives: N-ethyl-2-amino-1-phenylpropan-1-one (ethcathinone) hydrochloride and N-ethyl-2-amino-1-(4chlorophenyl)propan-1-one (4-CEC) hydrochloride. Forensic Toxicol. 2017, 35, 114-124. [CrossRef] [PubMed]

52. Archer, R.P. Fluoromethcathinone, a new substance of abuse. Forensic Sci. Int. 2009, 185, 10-20. [CrossRef] [PubMed]

53. Guirguis, A.; Girotto, S.; Berti, B.; Stair, J.L. Identification of new psychoactive substances (NPS) using handheld Raman spectroscopy employing both 785 and 1064nm laser sources. Forensic Sci. Int. 2017, 273, 113-123. [CrossRef] 